This is the final peer-reviewed accepted manuscript of:

Martelli G, Giacomini D.

Antibacterial and antioxidant activities for natural and synthetic dual-active compounds. Eur J Med Chem. 2018 Oct 5;158:91-105. doi: 10.1016/j.ejmech.2018.09.009. Epub 2018 Sep 5. PMID: 30205261.

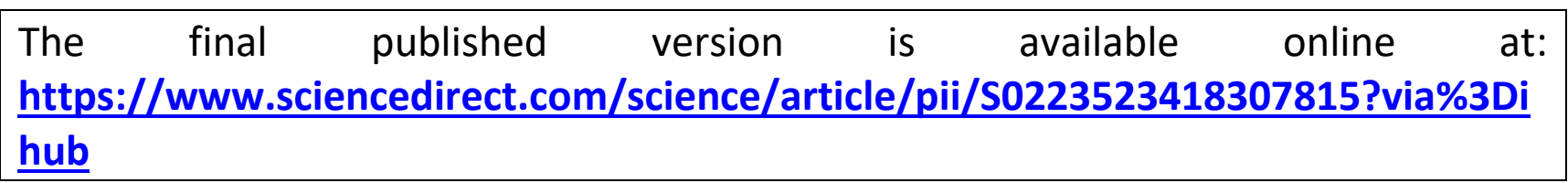

Rights / License:

The terms and conditions for the reuse of this version of the manuscript are specified in the publishing policy. For all terms of use and more information see the publisher's website.

This item was downloaded from IRIS Università di Bologna (https://cris.unibo.it/)

When citing, please refer to the published version. 


\title{
Antibacterial and antioxidant activities for natural and synthetic dual- active compounds
}

\author{
Giulia Martelli, Daria Giacomini* \\ Department of Chemistry "G. Ciamician", University of Bologna, Via Selmi 2, 40126, Bologna, Italy
}

Keywords:

Antimicrobial resistance

Antibacterial

Antioxidant

Natural products

Polyphenols

Lactams

Dual target compounds

Multigenic diseases

\section{A B S T R A C T}

Antimicrobial resistance is widely recognized as a grave threat to global health in the 21st century, since the past decades have seen a dramatic increase in human-pathogenic bacteria that are resistant to one or multiple antibiotics. New antimicrobial agents are urgently required, particularly in the treatment of chronic infections such as cystic fibrosis, often associated with persistent colonization by drug-resistant pathogens and epithelial damage by pulmonary oxidative stress. In such events, it would be favourable to find agents that could have antioxidant and antibacterial activities combined in one molecule. The discovery of compounds that can show a dual-target activity considerably increased in the last years, reflecting the growing confidence that this new approach could lead to better therapeutic solutions for complex multigenic diseases. The aim of this review is to report those natural and synthetic compounds displaying significant antioxidant and antibacterial activities. In recent years there has been a growing attention on plant-derived antimicrobials as an alternative to antibiotics, for their efficacy and low tendency in developing bacterial resistance. Moreover, it was found that some natural products could enhance the activity of common antibiotics displaying a synergistic effect. We then report some selected synthetic compounds with an in-built capacity to act on two targets or with the combination in a single structure of two pharmacophores with antioxidant and antibacterial activities. Recent literature instances were screened and the most promising examples of dual-active antibacterial-antioxidant molecules were highlighted.

\footnotetext{
* Corresponding author.

E-mail address: daria.giacomini@unibo.it (D. Giacomini).
} 


\section{Introduction}

Over the last 20 years, the phenomenon of antibacterial resistance has been raising dangerous levels in all parts of the world. Whereas antibiotic resistance was once largely confined to hospitals and long-term care facilities, it has now emerged in community settings and represents one of the most pressing global public health concerns. New resistance mechanisms are emerging and spreading globally, threatening our ability to treat common infectious diseases. In extreme cases, multidrug-resistant bacteria are no longer susceptible to any of the licensed antibacterial agents and we are going to move toward a "post-antibiotic" era in which common infections and minor injuries cannot be healed. The World Health Organization (WHO) has identified antimicrobial resistance as one of the greatest threats to human health and has adopted a global action plan [1] that outlines specific objectives: to increase the awareness of the problem with effective communication and education; to strengthen the knowledge on the mechanisms and on the spread of resistance; to decrease the incidence of infections; and to optimize the use of antimicrobial agents, with particular attention being given to increasing investments in the development of new antimicrobial agents. The European Commission adopted in 2017 a dedicated action plan against antimicrobial resistance (AMR) [2]. This action boosted research, development and innovation which should provide novel solutions and tools to prevent and treat infectious diseases, improve diagnosis, and control the spread of AMR. The proposed AMR research strategy covers the full "One Health" spectrum, addressing human and animal health as well as the role of the environment and taking into account the priorities set out in the above mentioned WHO global action plan on AMR [1].

It was reported that oxidative stress could contribute to the selection of resistant bacterial strains since reactive oxygen species (ROS) revealed to be an essential driving force [3-5]. The involvement of oxidative stress in the mechanism of antibiotic-mediated cell death is unclear and subject to debate [6]. It has been shown that under aerobic conditions bactericidal antibiotics with specific targets in bacterial cells stimulate the production of harmful reactive oxygen species (ROS), which contribute to killing by these drugs $[7,8]$. On the contrary, several research groups provided convincing arguments against the ROS-mediated killing of bacteria by antibiotics $[9,10]$. With regard to antibiotic-induced ROS formation and its role in bacterial resistance, a number of studies have attempted to resolve the role of ROS and oxidative stress response in cell killing following drug treatments [11]. One of bacteria survival strategies is the ability to form biofilms and thus sessile biofilm communities. It was recently reported that oxidative stress could contribute to the phenomenon of pro-biofilm variants selection and $\mathrm{H}_{2} \mathrm{O}_{2}$-resistance since ROS revealed to be an essential driving force for the selection of variants of Pseudomonas aeruginosa strains [4]. This evidence was also recently confirmed by clinical evaluations in patients affected by diabetes and/or related cardiovascular diseases, becoming more susceptible to bacterial infections (nosocomial infections and infections related to specific diseases) and less reactive to pharmacological treatments [3].
Oxidative stress is generally considered the starting point for the onset of several diseases (i.e. tissues chronic inflammation, cancer) [12] and undoubtedly one of the major pathophysiological hallmarks of severe obstructive lung diseases, including chronic obstructive pulmonary disease and cystic fibrosis (CF) [13]. In CF, a severe genetic disease, the presence of oxidative stress is due to an increased production of ROS and to an impaired antioxidant status [14] that particularly arise during chronic pulmonary infections. Lungs in CF patients are exposed to a vicious cycle of infection, inflammation, and obstruction. Interrupting this cycle with innovative agents might slow the disease progression, improve the quality of life, and could delay respiratory failure.

The above-described phenomena point to the need for new therapeutic strategies in targeting anti-oxidant pathways together with new antibacterial agents able to fight chronic infections caused by multidrug resistant bacterial strains, and dual-target molecules could give a successful answer.

Bacterial contaminations or detrimental oxidative effects are critical issues also for materials and aqueous solutions in several fields (i.e. medical, food, cosmetics) and represent an important task for public health conservation. Today, additives and preventive measures of hygiene have been adopted to fight against pathogenic bacteria, but the development of antimicrobial compounds that can selectively act as food preservatives without increasing AMR should be of the utmost importance [15]. Apart from bacterial deterioration, the oxidation of fatty acids by radical species is one of the most important factors leading to food degeneration. The demand of new antioxidant agents has been increasing because of the long-term safety and a negative consumer perception of synthetic antioxidants as butylhydroxyanisole, BHA, and butylhydroxytoluene, BHT, which showed toxic and carcinogenic side effects in animal models [16]. The discovery of compounds that can have both antimicrobial and antioxidant activities with no toxic effects on health is therefore highly awaited.

\section{Natural products with dual antibacterial and antioxidant activities}

Natural products have been playing an important role in drug discovery, even in the area of infectious diseases [17]. Natural antimicrobial agents can be obtained from different sources including plants, animals, bacteria, algae, and fungi, but there has been an increased interest in plant-derived antimicrobials as an alternative to the common antibiotics [18,19]. In addition to their efficacy, a significant advantage would be that bacteria should be less prone to develop resistance because natural compounds could be able to concurrently address more than one bacterial target. Moreover, certain plant-derived antimicrobials are labeled as "Generally Recognized as Safe" (GRAS), with a "greener" image that would be more acceptable to consumers [20]. All these factors suggest that plant-based antimicrobials could have a significant value in healthcare and market since they match the increasing demand for greener products by consumers, thus supporting the value of the research of new potential biopharmaceutical products [21]. However, there has been limited research related to the 
structure-activity relationships (SAR) for these plant-derived compounds, and the importance of the chemical composition of plant extracts related to the antimicrobial activity is still not well understood [22].

An important property of some natural products is to increase the efficacy of common antibiotics in several ways, such as on enhancing the membrane permeability, on inhibiting the synthesis of enzymes, or on blocking biochemical reactions. However, the synergistic effect of these combinations in comparison with standard drugs alone has not been yet evaluated by clinical studies. There are many examples of mono- and multi-extract combinations which exhibit synergistic effect based on multi-target mechanisms of action [23]. Moreover, the potentiating capacity of natural products on the anti-biofilm effect of antimicrobial compounds opens the possibility for a combined antimicrobial therapy [24]. Thus, the search for substances of natural origin for the development of new antibacterial drugs remains an important strategy in the fight against bacterial resistance [25].

In this section, we reviewed those natural molecules that have both antioxidant and antibacterial activities with significant potencies, whereas complex natural extracts were not covered. Compounds acting as enhancers of the effect of classical antibiotics, or as disrupters of bacterial biofilm were also considered and particular attention has been paid to recent literature.

\subsection{Polyphenolic compounds}

Plants produce a vast repertoire of secondary metabolites such as essential oils, alkaloids, terpenoids, phenolics and peptides in their normal metabolic pathways. These metabolites play a major role in protecting plants from microbial infections, pests, and UV radiations while attracting pollinators and dispersing seedsanimals.

Antimicrobial properties of some essential oils (EOs) are well known and are mainly attributed to the presence of terpenes, terpenoids, and aromatic compounds [26,27]. On the other hand, several essential oils also display good antioxidant properties which play a pivotal role in their biological activities [28]. The complex bioactive composition of essential oils interacts with multiple bacterial cellular targets instead of displaying a particular single mode of action, thus inhibiting pathogens from acquiring resistance [29].

Essential oils are complex volatile mixtures which consist of about 20-60 compounds in various concentrations where two or three major components are present at relatively high concentrations $(20-70 \%)$ compared to the others. Although the biological properties of EOs are found to be closely related with the major components, essential oils exert greater antibacterial activity compared to the major components alone. It was supposed that the function of the main compounds might be regulated by other minor ones which could have a potentiating synergistic effect [30].

Among several plant-derived substances, polyphenolic compounds have great structural diversity and variations in chemical composition, and thus differ in their antibacterial effectiveness against pathogenic microorganisms [31]. The most widely occurring plant phenolic compounds include phenolic acids, flavonoids, tannins, lignans, and terpenes [32].

Bioactive monoterpenes, such as thymol and carvacrol, found mainly in thyme and oregano essential oil, and phenylpropanoids such as eugenol found mainly in clove essential oil, indicated substantial antimicrobial activities against both Gram-positive and Gram-negative bacteria (Fig. 1). Lambert and colleagues [33] reported that carvacrol and thymol possess the ability to disintegrate the outer membrane of Gram-negative bacteria and to disrupt the cell membrane of Gram-positive bacteria, thus counteracting the

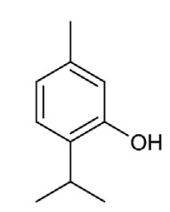

Thymol

E. coli $\mathrm{MIC} 2.5 \mu \mathrm{g} / \mathrm{mL}$

S. aureus $\mathrm{MIC} 2.5 \mu \mathrm{g} / \mathrm{mL}$
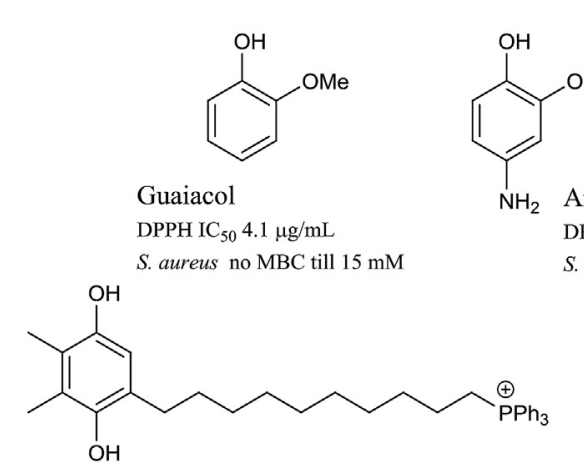

Carvacrol

E. coli $\mathrm{MIC} 2.5 \mu \mathrm{g} / \mathrm{mL}$

S. aureus $\mathrm{MIC} 1.25 \mu \mathrm{g} / \mathrm{mL}$

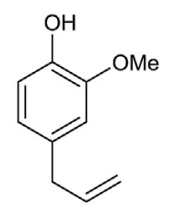

Eugenol

E. coli $\mathrm{MIC} 2.5 \mu \mathrm{g} / \mathrm{mL}$

S. aureus MIC $2.5 \mu \mathrm{g} / \mathrm{mL}$
Fig. 1. Selected examples of natural phenols and a synthetic variant.

'reduced membrane permeability' mechanism employed by multidrug-resistant strains. Thymol, carvacrol and eugenol are used as antiseptics in medicine, agriculture, cosmetics and in the food industry. Using simple synthetic approaches, a variety of biologically active derivatives of thymol, carvacrol and eugenol was recently discussed with respect to their biological activities especially as antibacterial [34] and antioxidant agents [35]. As a general observation, for most of the plant-derived phenolics and flavonoids the antibacterial potency could be in some cases considered modest (MIC values of $100-1000 \mu \mathrm{g} / \mathrm{mL}$ in susceptibility tests against bacteria) compared to that exhibited by the commonly used antimicrobial drugs which are more than hundred-folds stronger, with MIC in the range of $0.01-10 \mu \mathrm{g} / \mathrm{mL}$.

Martins et al. [36] provided a critical review on some aspects related with the in vivo antioxidant activity of phenolic extracts and plant-derived compounds, because of a poor consideration of biochemical, metabolic and other physiological parameters. Not only natural but also synthetic antioxidants suffer from numerous biochemical reactions along ingestion, digestion and absorption by the organism. For this reason, the effective bioavailability of antioxidants is not clearly defined: while many are ingested on their active form, others need to be metabolized to be biologically active, or could even become inactive. Furthermore, the co-ingestion of other nutrients, endogenous factors, and inter- and intra-individual variations, affect their bioavailability in relation to the ingested dose [37]. This fact explains why some plant species and even some isolated compounds did not evidence in vitro positive effects, but a strong antioxidant potential was observed when in vivo studies were carried out, and vice versa.

Many comparative studies reported that phenolic compounds have very interesting biological properties and are very active molecules compared to other natural products, but on the other hand they could display some drawbacks such as possible allergenic issues and a likely hydrophobic character [38]. An alternative could be the incorporation of active phenols within a polymeric structure, in many cases polysaccharides since they are natural, biocompatible, and biodegradable [39]. Moreover, these natural polymers present interesting viscosity and/or gelling properties with several possible applications also in food and cosmetic 
industries. As an example, Liu et al. [40] synthesized a polymer using an acrylamide monomer derived from the natural compound guaiacol which possesses interesting antibacterial, antifungal, and antioxidant properties (Fig. 1). The new polymers were highly effective against the adhesion of bacteria and prevented the formation of biofilm in strains of Bacillus subtilis. As a recent example, aminoguaiacol was chemically grafted onto the polysaccharide carboxymethyl pullulan, and antibacterial and antioxidant tests indicated that the new polymer was an active system with combined properties: against S. aureus displayed 93\% growth inhibition at $25 \mathrm{~g} / \mathrm{L}$ of polymer; scavenging activity against DPPH radical was found $13-179 \mu \mathrm{g} / \mathrm{mL}$ (IC 50 range) [41].

Compound SkQ1 is an interesting synthetic polyphenol which combines a 1,4-dihydroxybenzene with a triphenylphosphonium cationic head able to target mitochondria (Fig. 1). It was initially studied to release kidney damages in bacterial pyelonephritis by reducing mitochondrial ROS [42]. Plotnikov et al. showed that SkQ1 has a higher antioxidant potency than Trolox (a water-soluble analog of Vitamin E commonly used as reference standard for antioxidant potency measurements). In the context of acute infections, a therapeutic potential of SkQ1 as a mitochondrial antioxidant was then suggested. More recently, SkQ1 was also recognized as an effective antibacterial agent against $S$. aureus, B. subtilis, E. coli, and Mycobacterium sp. (see Fig. 1 for selected MIC data) [43]. The mechanism of the bactericidal action of SkQ1 could be ascribed to its ability to decrease the bacterial membrane potential. Considering the association of the antibacterial activity with the antioxidant one, SkQ1 can be really considered a new type of dual-acting "hybrid" antibiotic.

\subsection{Vanillin and derivatives}

Vanillin (4-hydroxy-3-methoxybenzaldehyde) is a phenolic aldehyde used as flavoring agent in foods (Fig. 2). It accumulates in the pods of the orchid Vanilla planifolia as a glycoside, glucovanillin, which is considered an antimicrobial and antioxidant agent. Vanillin itself has a very low antibacterial activity, but some derivatives showed an interesting potency. It was reported that some vanillin-imines (Fig. 2) are active against E. coli with MIC $0.28 \mu \mathrm{g} / \mathrm{mL}$ [44]; antioxidant and antimicrobial activities were observed for some vanillin derived piperidin-4-one oxime esters (Fig. 2) and the preponderant effect of the aryl-ester substituents on the biological activity was demonstrated [45]. The antioxidant activity was improved by aryl fragments such as 3,4,5-trihydroxy-phenyl group (DPPH IC $5010 \mu \mathrm{M}$ ), whereas the best antibacterial activity was reported for 4-F or 4-Cl-phenyl derivatives (inhibition zone $13 \mathrm{~mm}$ at $500 \mu \mathrm{g} / \mathrm{mL}$ for S.aureus, E. coli, and P. aeruginosa) [45].

A synergistic effect of vanillin was observed when it was associated with some antibacterial drugs such as gentamicin and imipenem against strains of $S$. aureus. and $E$. coli, but not with norfloxacin, tetracycline, or erythromycin. On the other hand, with
$P$. aeruginosa the effect was found to be dependent on the drug: the association of vanillin with norfloxacin had a synergistic effect, tetracycline and erythromycin showed an antagonistic effect, whereas the activities of gentamicin and imipenem were not significantly altered by the combination [46].

\subsection{Resveratrol}

Resveratrol is a naturally occurring phytoalexin belonging to the stilbene family of phenolic compounds, present in over 100 medical and edible plants (Fig. 3). In particular, resveratrol is found in the skin and leaves of grapevine [47]. Phytoalexins are low molecular weight secondary metabolites produced by plants in response to adverse conditions such as biotic stress from bacteria, fungi, viruses, and abiotic stress from chemical treatments [48].

Resveratrol has been gaining considerable attention in the medical field due to its biological activities: it has been reported to exhibit antioxidant, cardioprotective, anti-diabetic, anticancer, and antiaging properties. The antioxidant potency was recently evaluated with different methods [49] and reported as TEAC (Trolox equivalent antioxidant capacity) as depicted in Fig. 3.

Foodborne pathogens have a significant health impact and the emergence of resistant strains due to the excessive use of antibiotics enhances the difficulty in effectively treating infections as a result of contaminated food. Resveratrol exhibits antibacterial activity against different foodborne pathogens including Staphylococcus aureus, Bacillus cereus, Bacillus subtilis, and Listeria monocytogenes (Gram-positive), E. coli, Salmonella typhimurium, Vibrio cholera, Campylobacter jejuni, Campylobacter coli, Arcobacter butzleri, and Arcobacter cryaerophilus (Gram-negative) [50]. In a study of Ma et al. [50], a better activity of resveratrol against Grampositive bacteria compared to the Gram-negative was observed: the minimum inhibitory concentration (MIC) against Gramnegative ranged from 0.625 to $521 \mu \mathrm{g} / \mathrm{mL}$ while against Grampositive bacteria ranged from 16.5 to $260 \mu \mathrm{g} / \mathrm{mL}$. Paulo et al. [51] proposed that the difference in susceptibilities toward resveratrol might be attributed to the presence of a hydrophilic outer membrane in Gram-negative bacteria which is absent in Gram-positive. The outer membrane may act as a protective layer resisting the diffusion of hydrophobic molecules like resveratrol from penetrating the bacterial cell, thereby reducing the efficacy of the antibacterial action.

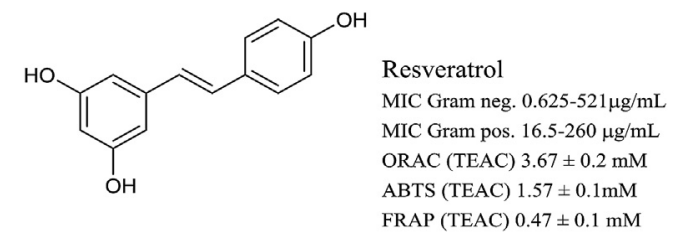

Fig. 3. Resveratrol and selected values of antioxidant and antibacterial activities.

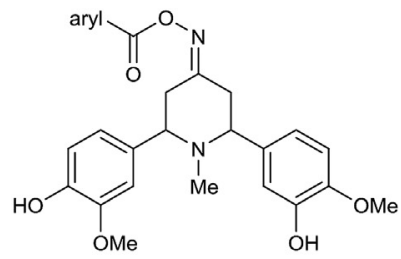

Vanillin derived piperidin-4-one oxime esters

Vanillin-imine

E. coli $\mathrm{MIC} 0.28 \mu \mathrm{g} / \mathrm{mL}$

S. aureus $\mathrm{MIC} 2.03 \mu \mathrm{g} / \mathrm{mL}$

Fig. 2. Vanillin and selected derivatives. 
Combinatorial therapy could be a strategy to address the differential susceptibility toward resveratrol as it could potentially enhance the efficacy of antimicrobials, and prevent the emergence of resistant strains. It was reported a synergistic activity of resveratrol and antibiotic drugs showing an improved antibacterial activity compared to the treatment with resveratrol or antibiotics alone [52]. The study revealed a synergism between resveratrol and ciprofloxacin, and an additive effect between resveratrol and cefotaxime against both Gram-negative or Gram-positive bacteria [52].

The exact mechanism of resveratrol activities against bacterial pathogens is still elusive. Nevertheless, several studies have reported some possible mechanisms of action which include DNA damage, cell division impairment, metabolic enzymes inhibition and oxidative membrane damage [53,54], thus strengthening the synergy of the antibacterial with the antioxidant activities. On the contrary, recent results highlighted the importance of possible antagonistic effects by co-administration of resveratrol with antimicrobial agents that have a ROS-mediated action, or in combination with a photodynamic therapy (visible radiation and methylene blue). As an example, it was observed that the antimicrobial potency of therapies with levofloxacin against planktonic $S$. aureus strains are significantly diminished in the presence of resveratrol [55]. It was also examined the possibility that resveratrol could interfere with antimicrobial lethality and the recovery of resistant bacterial mutants [56]. Resveratrol was added to cultures of Escherichia coli and Staphylococcus aureus that were then treated with antimicrobial as ciprofloxacin, kanamycin, or daptomycin, and assayed for bacterial survival. It was reported that sub-inhibitory concentrations of resveratrol promoted (2- to 6-fold) the recovery of rifampicin-resistant mutants and the suppression of antimicrobial lethality. Zhou et al. reported an enhancement of susceptibility to aminoglycoside antibiotics on recent clinical isolates of $P$. aeruginosa by co-administration of resveratrol [57]. P. aeruginosa bacteria cause severe infections with high morbidity and mortality, particularly in CF patients and intensive care unit patients [57]. Such infections are difficult to treat because of high levels of virulence factors and formation of biofilms. It was observed by SEM and fluorescence microscopy that resveratrol could modify the bacterial biofilm structure thus resulting in an increased efficacy in combination with gentamycin and amikacin [57].

Biofilms produced by pathogenic foodborne bacteria can cause serious health risks due to their inherent resistance to antimicrobial agents, to host defenses and external stresses which make them difficult to eradicate. Awareness of this impending risk spurred the search for alternative antimicrobial additives and natural plant-derivatives could be promising candidates because of their good acceptability and likely low toxicity levels since they have long been used in traditional medicines [58]. Differential activities of resveratrol in inhibiting the formation of biofilms and in eradicating the already formed ones were observed against specific foodborne pathogens. Previous works demonstrated that resveratrol appears effective in preventing biofilm diffusion by $S$. aureus [59,60], L. monocytogenes [61], E. coli O157:H7 [62], Campylobacter sp. [63] and $V$. cholerae [64]. Qin et al. [60] demonstrated that resveratrol caused $39.85 \%$ inhibition of methicillin-resistant S. aureus (MRSA) biofilm formation at $100 \mu \mathrm{g} / \mathrm{mL}$ and $23.42 \%$ removal of a preformed biofilm at $150 \mu \mathrm{g} / \mathrm{mL}$.

\subsection{Curcumins}

Curcumin is a yellow-orange hydrophobic compound extracted from Curcuma longa and widely used by oriental cultures. It displays good tolerability and safety profiles and discloses numerous biological properties $[65,66]$, including anti-inflammatory and antioxidant activities [67-69] (Fig. 4). Overall curcumin and analogs have long been known to be antimicrobial agents against both Gram-positive and Gram-negative bacteria, and have been used also as a preservative [70,71]. The antimicrobial mechanism of curcumin involves the interaction with the protein FtsZ essential as cell division initiating agent in bacteria [72], and experimental data support that the methoxy- and hydroxyl groups are directly involved in the antimicrobial activity.

Notwithstanding its considerable biological properties, curcumin exhibits a number of drawbacks: low solubility in water and deterioration at neutral to basic $\mathrm{pH}$ conditions; moreover, it is also found to be photosensitive and requires careful handling. Several formulation strategies like nanoparticles, liposomes, complexation with phospholipids and cyclodextrins, solid dispersions and nanoformulations are being developed to improve physico-chemical properties of curcumin and its bioavailability [73,74].

Synergistic combinations of curcumin and the aminoglycoside antibiotic Amikacin induced a reduction in microbial aggregates of clinical isolates of Mycobacterium abscessus and a substantial loss in cell viability [75]. Moreover, disruption of biofilms was the main detected effect with curcumin thus supporting a previous evidence that curcumin could be a potential breaker of antibiotic resistance.

The design and synthesis of new curcumin derivatives has been growing in recent years, and a series of pyrazole-curcumin bisacetamides were obtained with good antioxidant, antiinflammatory, and antibacterial activities [76]. Emam et al. recently reported the synthesis of a novel series of curcuminoid analogs [77] to be evaluated in their antioxidant and antibacterial properties: the majority of the tested compounds showed good inhibitory effects on Gram-positive bacteria (Bacillus subtilis and Staphylococcus aureus), stronger than those found for Gramnegative pathogens (Escherichia coli and Pseudomonas aeruginosa), together with a significant antioxidant ability to scavenge free radicals. A promising candidate with a hydrazine-thione moiety is depicted in Fig. 4.

\subsection{Hydroxycinnamic acids and chlorogenic acids}

Cinnamic acids (CADs) exhibit a wide range of biological activities, such as scavengers of free radicals, antioxidants, protecting agents against ultraviolet radiation, antibacterial and antiviral compounds. Hydroxycinnamic acids and their derivatives are widely distributed in cereals, legumes, oilseeds, fruits, and vegetables. The most common hydroxycinnamic acids include coumaric, caffeic, ferulic, and sinapic acids [78] (Fig. 5). Among others, ferulic acid is particularly abundant in fruits and vegetables and over the past years, several studies have demonstrated its action as a potent antioxidant by scavenging free radicals and enhancing the cell stress response [79-81]. Relying on the antibacterial activity, a significant potency was restricted to some CADs derivatives [82,83] such as esters [81] or amides [84]. Rosmarinic acid (RA) is an example of a natural ester of CADs showing modest antibacterial potency but high antioxidant and anticancer activities (Fig. 5) [85]. As an example of saturated derivatives, phloretin and its glucoside phloridzin, isolated from Golden Delicious pomace, showed interesting combined antibacterial and antioxidant activities [86].

A further development consisted in uploading cinnamic acids on natural polysaccharides such as chitosan [87]. Unfortunately, the conjugate CADs-chitosan showed lower values of antioxidant activity (DPPH $\mathrm{IC}_{50}$ in the range $135-230 \mu \mathrm{g} / \mathrm{mL}$ ) than CADs alone (data in Fig. 5). Considering the antibacterial activity against $S$. aureus strains and foodborne pathogens, some interesting excerpt data of CADs-chitosan conjugates are: MRSA MIC range $32-128 \mu \mathrm{g} / \mathrm{mL}$, MSSA MIC range 16-64 $\mu \mathrm{g} / \mathrm{mL}$, and Bacillus subtilis MIC range $2-64 \mu \mathrm{g} / \mathrm{mL}$. 


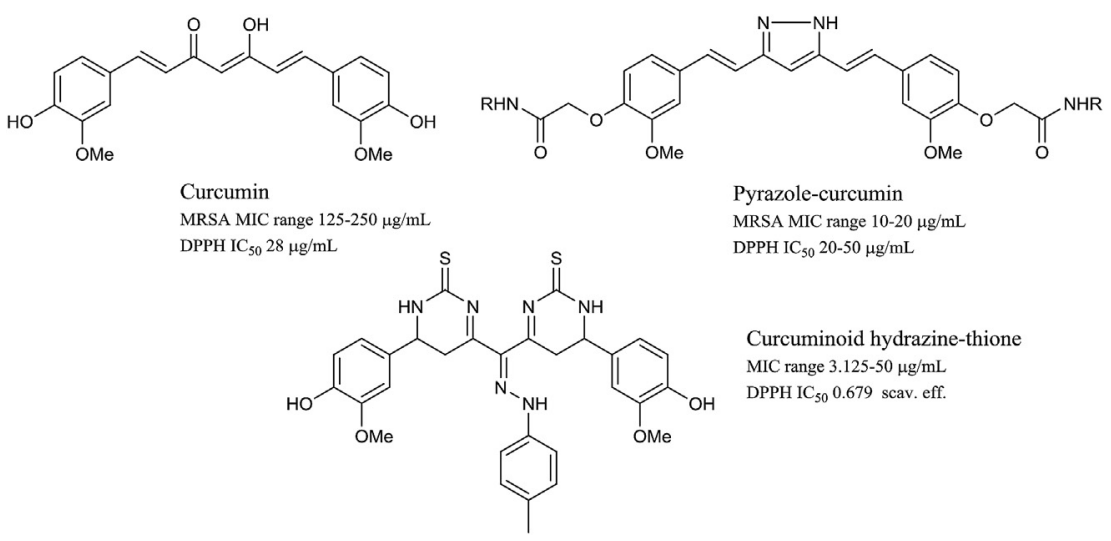

Fig. 4. Curcumin and curcuminoid derivatives.<smiles>COc1cc(/C=C/C(=O)O)ccc1O</smiles><smiles>COc1cc(/C=C/C(=O)O)cc(OC)c1O</smiles>

Sinapic acid<smiles>O=C(CCc1ccc(O)cc1)c1c(O)cc(O)cc1O</smiles>

Phloretin E. coli $\mathrm{MIC} 0.25 \mathrm{mg} / \mathrm{mL}$ S. aureus $\mathrm{MIC} 0.1 \mathrm{mg} / \mathrm{mL}$ DPPH $1.27 \mathrm{mg}$ eq.BHT<smiles>[R20]/C=C/c1ccc(O)c(O)c1</smiles>
$\mathrm{C}_{50} 0.4 \mu \mathrm{g} / \mathrm{mL}$<smiles>O=C(CCc1ccc(O)cc1)c1c(O)cc(O)cc1O</smiles>

Phloridzin

E. coli MIC $1.5 \mathrm{mg} / \mathrm{mL}$

S. aureus MIC $0.5 \mathrm{mg} / \mathrm{mL}$ DPPH $0.89 \mathrm{mg}$ eq.BHT

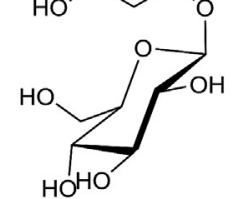

Fig. 5. Selected natural cinnamic acids and derivatives.

The term 'chlorogenic acids' (CGAs) or acylquinic acids encompasses a large group of naturally-occurring compounds that are mainly synthesized in planta by esterification of hydroxycinnamic acids with $1 L-(-)$-quinic acid (Fig. 6). Subgroups of acylquinic acids are constituted by several regio-isomers that are defined by the number and identity of the constituent hydroxycinnamic acid [88] (Fig. 6). Many plants produce acylquinic acids in which esterification occurs at positions 3, 4 and 5 of the quinic acid moiety and multiple isomers usually co-exist, but chlorogenic acid is one of the most abundant among caffeoylquinic acid isomers.

Acylquinic acids are widespread dietary components being found, for instance, in coffee, cherries, blueberries, aubergines, apples, oregano, spearmint, chicory and sunflower seeds. Coffee beverages, rather than fruits and vegetables, are probably the main dietary source of CGAs for many people, being readily attained intakes of $1 \mathrm{~g}$ per day. Chlorogenic acids are important and biologically active dietary polyphenols, playing several important and therapeutic roles. Acyl-quinic acids are frequently referred to powerful antioxidants [89] and caffeoyl-quinic acids demonstrated both inhibitory effects on carcinogenesis in the large intestine, liver, tongue, and protective effects against oxidative stress in vivo [90]. Other important biological activities were reported as hepatoprotective, cardio-protective, anti-inflammatory, antipyretic, neuroprotective, anti-obesity, antiviral, anti-microbial, anti-hypertension, free radicals scavenger, and central nervous system (CNS) stimulator [88,90]. In addition, CGAs could modulate lipid and glucose metabolism in both genetically and healthy metabolicrelated disorders [91]. CGA displays also various antimicrobial effects which makes it suitable as an ideal preservative and food additive. Studies have indicated that CGA has bactericidal effects against Stenotrophomonas maltophilia resistant to trimethoprim/ sulfamethoxazole, Klebsiella pneumoniae, Helicobacter pylori, Escherichia coli, Staphylococcus epidermidis, and Staphylococcus aureus [88]. Fiamegos et al. [92] observed a potentiation of some common antibacterial agents against MRSA by 4,5-O-dicaffeoylquinic acid which, as an efflux pump inhibitor, possesses a potential capacity of targeting efflux systems in resistant bacteria. 


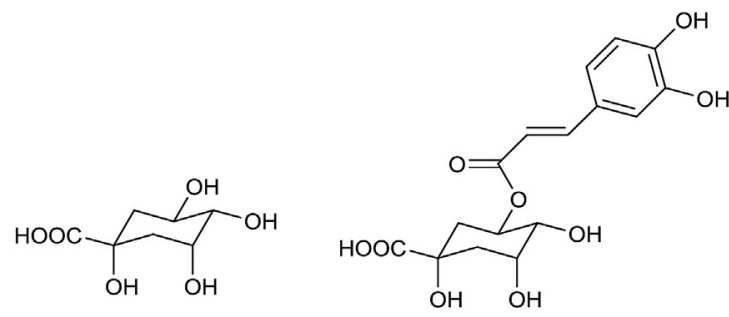

Quinic acid

5-O-caffeoyl-quinic acid (chlorogenic acid) S.aureus, E. faecalis MIC range $32-128 \mu \mathrm{g} / \mathrm{mL}$ $\mathrm{DPPH} \mathrm{EC}_{50} 13.8 \mu \mathrm{g} / \mathrm{mL}$<smiles>O=C(O)C1(O)CC(O)C(O)C(O)C1</smiles>

3-O-caffeoyl-quinic acid (neochlorogenic acid) $\mathrm{DPPH} \mathrm{EC}_{50} 13.4 \mu \mathrm{g} / \mathrm{mL}$

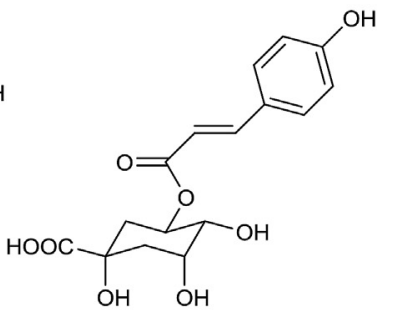

5-O-coumaroyl-quinic acid<smiles>COc1cc(/C=C/C(=O)OC2CC(O)(C(=O)O)CC(O)C2O)ccc1O</smiles>

3-O-feruloyl-quinic acid

Fig. 6. Selected examples of chlorogenic acids.

\subsection{Triterpenoid acids}

Triterpenoids belong to terpenoids (also known as isoprenoids), the largest group of natural products [93]. These compounds consist of six isoprene units and can be isolated from many different plant sources. Betulin, betulinic acid and ursolic acid (triterpenoids) are found in fruits and have been reported to possess several pharmacological activities including antibacterial, antiviral, anti-HIV, antitumor and antioxidant. Oloyede et al. pointed to the involvement of ROS generation for inducing bacterial lethality with betulin acid and ursolic acid [94] (Fig. 7). Ursolic acid is present in many medicinal plants, such as Rosmarinus officinalis, or in aerial parts of Sambucus australis, and it is isolated also from apple peeling. Its derivatives have been outlined as possessing antibacterial, antioxidant, anticancer, and anti-ulcer potentials [95-97]. The antibacterial properties of this pentacyclic triterpene and its analogs have been extensively studied and found to be related to their ability in enhancing bacterial susceptibility to antibiotics [97,98]. It was also demonstrated that ursolic acid, as resveratrol and curcumin, is able to inhibit MRSA biofilm production [60].

\subsection{Coumarins}

Coumarins comprise a very large class of compounds found throughout the plant kingdom. They are present at high levels in some essential oils, particularly cinnamon bark oil, cassia leaf oil and lavender oil, but also in fruits (e.g. bilberry, cloudberry), green
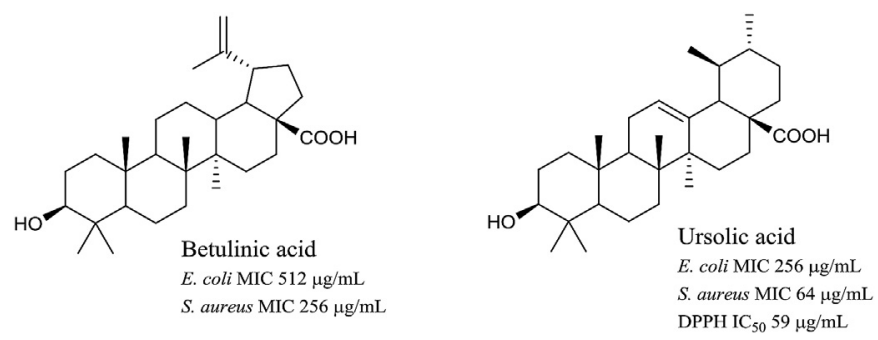

Fig. 7. Natural triterpenoids: betulinic and ursolic acids. tea and other foods such as chicory [99,100]. Even if coumarin itself has a very low antibacterial activity, some derivatives as coumarinyl pyrazoles [101] and amino derivatives of 4-hydroxycoumarins [102] showed antioxidant and modest antibacterial activities (Fig. 8). The endophytic fungus Alternaria sp. Samif01 isolated from Salvia miltiorrhiza Bunge produced some bioactive compounds, including dibenzo- $\alpha$-pyrones that could be considered a sort of benzocoumarins. Some of these isolated compounds showed a low antibacterial activity but appreciable antioxidant effects in hydroxyl radical assays [103].

\subsection{Mollugins}

Mollugin is one of the major chromenes isolated from Rubiaceae species such as Putoria calabrica and Rubia cordifolia, a medicinal plant used in China and India possessing anti-hemorrhage, antimutagenic, and antiviral activities and used for the treatment of a range of conditions including arthritis, rheumatism and menstrual pain. The natural compounds mollugin and furomollugin showed very poor or null antibacterial activity, whereas the acid of mollugin (Fig. 9) showed potency similar to ciprofloxacin [104]. Synthetic analogs of furomugillin bearing a dihydronaphtho-furan skeleton displayed equipotential activity against $E$. coli and $S$. aureus strains compared to the standard drug Ampicillin ( $\mathrm{MIC}=0.5-2 \mu \mathrm{g} / \mathrm{mL}$ ) together with a potent antioxidant activity as DPPH scavengers $\left(\mathrm{IC}_{50}=3.3-22.7 \mu \mathrm{g} / \mathrm{mL}\right)$ [104-106].

\section{New dual active molecules by design and synthesis}

Our understanding of the pathogenesis of diseases has advanced enormously in recent decades. However, many pathologies are multifactorial and cannot be treated acting on a single biological target, since they depend on multiple genetic factors, and sometimes also on environmental aspects. Drugs hitting a single target may be thus inadequate for the treatment of diseases like neurodegenerative syndromes, diabetes, cardiovascular diseases, and cancer, which involve multiple pathogenic factors [107]. In order to gain multi-targeting in a single therapy solution, two approaches are possible: the selection of molecules with inbuilt capacity to act on two or more targets, and/or the combination of two or more 
<smiles>[R]c1ccc(NC(C)c2c(O)c3ccccc3oc2=O)cc1</smiles><smiles>Cc1nn(C(=O)COc2ccc3c(C)cc(=O)oc3c2)c(C)c1/N=N/c1ccc(Br)cc1</smiles>

Coumarinyl pyrazole

S. aureus $12.7 \mathrm{~mm}$ (inhibition zone at $250 \mathrm{mcg} /$ disc conc.) DPPH $55 \%$ scav. eff. at $0.2 \mathrm{mM}$

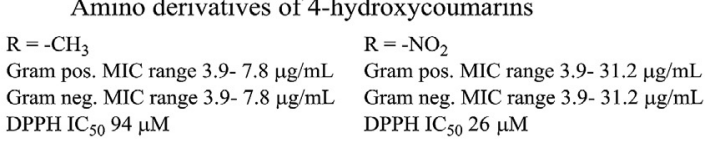<smiles>COc1cc(O)c2c(=O)oc3c(O)c(O)cc(C)c3c2c1</smiles>

Dibenzo- $\alpha$-pyrone

B. subtilis $\mathrm{IC}_{50} 29 \mu \mathrm{M}$

P. syringae $\mathrm{IC}_{50} 7 \mu \mathrm{M}$

hydroxyl radical scav. $\mathrm{EC}_{50} 68.3 \mu \mathrm{M}$

Fig. 8. Selected coumarin derivatives.<smiles>CC(=O)c1c2c(c3ccccc3c1O)OC(C)(C)C=C2</smiles><smiles>CC1(C)C=Cc2c(c(C(=O)O)c(O)c3ccccc23)O1</smiles><smiles>CC(=O)c1c(O)c2ccccc2c2occc12</smiles>

Mollugin DPPH IC ${ }_{50} 0.7 \mu \mathrm{g} / \mathrm{mL}$

\section{Mollugin acid}

DPPH IC $5042.5 \mu \mathrm{g} / \mathrm{mL}$

\section{Furomollugin} DPPH IC ${ }_{50}>100 \mu \mathrm{g} / \mathrm{mL}$<smiles>CC(=O)c1c2c(c3ccccc3c1O)O[C@@H]1OCCC[C@H]21</smiles><smiles>CCCOC1Cc2c(c(C(C)=O)c(O)c3ccccc23)O1</smiles>

synthetic derivatives

S. aureus MIC $2 \mu \mathrm{g} / \mathrm{mL}$ DPPH IC $5022.7 \mu \mathrm{g} / \mathrm{mL}$
S. aureus MIC $0.5 \mu \mathrm{g} / \mathrm{mL}$ DPPH IC $\mathrm{I}_{50} 3.33 \mu \mathrm{g} / \mathrm{mL}$

Fig. 9. Natural and synthetic mollugins.

pharmacophores in a single hybrid molecule obtained exclusively by design and synthesis [108]. Not surprisingly, the considerable number of multi-target derivatives described in the last ten years points out the growing confidence that this new approach could lead to better therapeutic solutions for Alzheimer, Cystic Fibrosis and other complex multigenic diseases [109].

This section focuses on some examples of synthetic compounds combining in one structure antioxidant and antibacterial activities as two synergistic pharmacological properties that could provide new promising leads useful in adverse clinical conditions.

\subsection{Beta-lactam based compounds}

A valuable contribution in design and synthesis of new multitarget compounds could arise in the development of dual-active molecules effective as antioxidant and antibacterial agents in the treatment of chronic infections such as those developed in cystic fibrosis patients. In these patients high levels of systemic oxidative stress have been documented over the years [110], possibly leading to airways inflammation and to a progressive epithelial tissue damage [111]. In infectious conditions, the production of reactive oxygen species by activated neutrophils represents an important

mechanism to kill bacteria but, whereas in healthy individuals it is properly counteracted by endogenous antioxidants agents [110], in $\mathrm{CF}$ patients the defense systems are ineffective and an increased production of ROS may be associated with cell dysfunctions and disease progression [14].

In this context, a series of new monocyclic beta-lactams were successfully realized. The molecular structure of the derivatives is characterized by the presence of an alkylidene carboxyl chain or an electron-withdrawing group at the $\mathrm{C} 4$ position of the ring, and $\mathrm{N}$ unsubstituted and $\mathrm{N}$-thiomethyl scaffolds were compared (Fig. 10) [112]. An early library of the beta-lactam compounds presented an acetoxy group in C4 and was armed with polyphenolic side chains in order to activate the antioxidant activity which was evaluated by Briggs - Rauscher and TEAC tests. Few polyphenolic beta-lactams were also submitted to cell testing for the inhibition of ROS production in myoblast H9c2 cells [113]. The heart shows indeed a higher susceptibility to oxidative stress than other organs, such as liver for instance, because of a lower activity of antioxidant enzymes. So, it should be hypothesized that the administration of dual-active agents could have a synergic effect in counteracting cardiac oxidative stress that is one of the main consequences of sepsis. The scope of the previously developed compounds was later on broadened by functionalizing the antibacterial-core structure with an alkylidene chain at the C4 position of the beta-lactam ring, and polyphenolic moieties from some plant-derived benzoic and cinnamic acids on the C3 position [114,115].

Concerning antibacterial activity, the 4-alkylidene-azetidinones show a significant potency against Gram-positive pathogens [116]. The enhanced activity could be due to the carbon-carbon double bond directly linked to the ring which confers indeed an increased aptitude toward ring-opening reactions by suitable bacterial enzymes. The specific design of the new derivatives arose from the observation that the 4-alkylidene function with a $(Z)$ stereochemistry favors the biological activity if compared to $(E)$ stereoisomers and that the presence of a benzyl ester strongly improved the potency compared to the ethyl ester or the carboxylic acid [112]. The combination of an $\mathrm{N}$-SMe and an acetoxy group on the $\mathrm{C} 4$ position of the beta-lactam ring was found to enhance the potency against Gram-positive bacteria [112]. Derivatives with this structure were furthermore loaded on nanocrystals of hydroxyapatite for the obtainment of new functional biomaterials with enhanced antibacterial activity against resistant Staphylococcus aureus strains obtained from surgical bone biopsies [117].

In Fig. 10 are reported some examples of beta-lactams displaying the combined dual activity: in N-SMe-4-acetoxy beta-lactams 1a-c, the phenolic residue on the hydroxyethyl-side chain allowed the 
<smiles>[R]c1cc(C(=O)O[C@H](C)[C@H]2C(=O)N([R16])[C@H]2OC(C)=O)cc([R])c1O</smiles>

$\mathrm{R}=\mathrm{OCH}_{3}(\mathbf{1} \mathbf{a}), \mathrm{OH}(\mathbf{1 b})$ $\mathrm{R}^{\prime}=\mathrm{OCH}_{3}(\mathbf{1 a}), \mathrm{H}(\mathbf{1} \mathbf{b})$ MRSA MIC range 16-128 $\mu \mathrm{g} / \mathrm{mL}(\mathbf{1 a}), 32-128 \mu \mathrm{g} / \mathrm{mL}$ (1b) DPPH (TEAC) $0.037 \mathrm{mM}(\mathbf{1 a}), 1.23 \mathrm{mM}(\mathbf{1 b})$<smiles>[R]c1cc(/C=C/C(=O)O[C@H](C)[C@H]2C(=O)N/C2=C\C(=O)OCc2ccccc2)cc(OC)c1O</smiles>

$\mathrm{R}=\mathrm{H}(\mathbf{2 a}), \mathrm{OCH}_{3}(\mathbf{2 b})$

MRSA MIC range 4-8 $\mu \mathrm{g} / \mathrm{mL}$ (2a), $4-8 \mu \mathrm{g} / \mathrm{mL}$ (2b) DPPH (TEAC) $0.142 \mathrm{mM}(\mathbf{2 a}), 0.191 \mathrm{mM}(\mathbf{2 b})$<smiles>CSN1C(=O)[C@H](OC(C)=O)[C@H]1C(C)OC(=O)/C=C/c1ccc(O)c(O)c1</smiles>

MRSA MIC range $16-128 \mu \mathrm{g} / \mathrm{mL}$ DPPH (TEAC) $0.98 \mathrm{mM}$<smiles>C[C@H](OC(=O)c1ccc(O)c(O)c1)C1C(=O)N/C1=C\C(=O)OCc1ccccc1</smiles>

MRSA MIC range 4-16 $\mu \mathrm{g} / \mathrm{mL}$ DPPH (TEAC) $2.59 \mathrm{mM}$

Fig. 10. New dual active beta-lactam derivatives by design and synthesis to have antibacterial and antioxidant activities.

antioxidant potency conjugated with encouraging antibacterial activities [114]. Coupling a phenolic ester with $N$-methylthio-4alkylidene-beta-lactams resulted in inactivation [114], hence showing the need for an unsubstituted $\mathrm{NH}$ group on the betalactam ring.

As a general trend, to activate the antioxidant potency of the tested compounds to a significant extent, the presence of two or three phenolic $\mathrm{OH}$ groups is necessary, and the $\mathrm{OH}$ group on the $\mathrm{C}(3)$ of the phenyl ring considerably improved the activity [113]. It was found out that polyhydroxy-benzoates of beta-lactams presented a minor antioxidant activity if compared with simple polyhydroxy-benzoates methyl esters, probably due to steric hindrance [113]. Because of this issue, the linkage between the aromatic ring and the beta-lactam scaffold was extended by the insertion of a hydroxycinnamic moiety thus allowing a greater exposure of the phenolic $\mathrm{OH}$ residues that enhanced the antioxidant potency without affecting the antibacterial activity. As a result, some novel compounds (2a-c) with a better antibacterial activity against multidrug-resistant $S$. aureus strains from $C F$ clinical isolates (MIC ranges from 4 to $16 \mu \mathrm{g} / \mathrm{mL}$ ) and a considerable antioxidant potency have been achieved [115].

\subsection{Quinolines and dihydroquinolines}

Heterocyclic compounds containing quinoline nucleus are known to possess diverse pharmacological properties such as antioxidant, antibacterial, antiviral, antitumor and antiinflammatory [118-123]. In 2009 it was reported [124] a new class of 2-mercapto/2-selenobenzo[h]quinoline-3-carbaldehydes (3a-b) as dual-active compounds. These molecules have a quinoline ring system and an intramolecularly stabilized organoselenium or sulfur residue, recently discovered as playing an important role in the catalytic antioxidant activity [125]. Since it has been suggested that quinolines can also prevent free radical production in Fenton reaction [126] and react with free radicals in order to protect DNA from oxidative damage, antibacterial and antioxidant potentials of the newly designed scaffolds were evaluated. They resulted in the strong antioxidants in scavenging tests against various in vitro antioxidant systems (scavenging effect over superoxide anion, hydrogen peroxide and DPPH). In antibacterial assays against six different pathogens, the more significant MIC value was obtained for Gram-positive S. aureus and Streptococcus pyogenes bacterial strains (Fig. 11). Furthermore, wound healing and DNA binding activities were also studied, ranking these derivatives as interesting antibacterials, antioxidants, and wound healing agents.

In this contest, it is worth mentioning also a new series of $N, N^{\prime}-$ dialkyl substituted-1,4'-diaza-flavonium bromides containing quinoline nucleus [127]. $N$-Alkyl and $N, N^{\prime}$-dialkyl derivatives of diazaflavones have been reported to have antimicrobial and antibacterial activities [124]. This new class turned out to be active against six different bacterial strains and in particular a single derivative displayed a similar high potency against both Gram positive and Gram negative $S$. aureus and Pseudomonas aeruginosa with a MIC value of $7.8 \mu \mathrm{g} / \mathrm{mL}$ (Fig. 11). Also antioxidant activities in DPPH scavenging tests were remarkable. As a general structure-activity relationship, both biological potencies decreased with longer alkyl chain length on the nitrogen atoms, with the best candidate of the series (4a) bearing a hexyl residue.

\subsection{Piperidone-hydrazides}

The piperidin-4-one nucleus cover a special place in medicinal chemistry, representing a widely present substructure in natural alkaloids. It exhibits a broad spectrum of biological activities, ranging from antibacterial to anticancer. Furthermore, many researchers have focused on modifying the piperidin-4-one

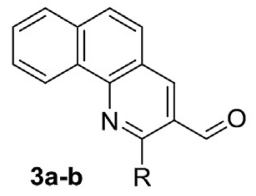

$\mathrm{R}=\mathrm{SH}(\mathbf{3 a}), \mathrm{SeH}(\mathbf{3 b})$

MIC range $11-32 \mu \mathrm{g} / \mathrm{mL}$ (3a), $6-25 \mu \mathrm{g} / \mathrm{mL}$ (3b) DPPH $55 \%$ scav. eff. (3a), $61 \%$ scav. eff. (3b)

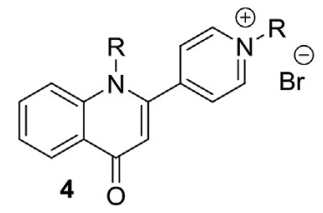

$\mathrm{R}=\mathrm{C}_{6} \mathrm{H}_{13}$

P. aeruginosa $\mathrm{MIC} 7.8 \mu \mathrm{g} / \mathrm{mL}$

S. aureus MIC $7.8 \mu \mathrm{g} / \mathrm{mL}$ $\mathrm{DPPH} \mathrm{SC}_{50} 56 \mu \mathrm{g} / \mathrm{mL}$
Fig. 11. Dual active quinoline and dihydroquinoline derivatives. 
pharmacophore in order to obtain better biological properties [129-131]. In particular, the addition of a hydrazide into the piperidin-4-one scaffold to produce the corresponding hydrazones resulted in compounds with promising antioxidant, anticancer, antifungal, and antimicrobial activities [128]. Hydrazide/hydrazone derivatives, in fact, received particular attention in medicinal chemistry field as a result of their effective contribution to antimicrobial, antitubercular, and anticonvulsant properties [130,131-134]. Among the newly synthesized library, those derivatives possessing $p$-fluoro substituents at aryl ring in the piperidine moiety (Fig. 12, 5a-b) displayed enhanced inhibitory effects against different bacterial strains (B. subtilis, $P$. aeruginosa, $K$. pneumoniae, $S$. aureus, and $E$. coli) with MIC values range of $3.12-25 \mu \mathrm{g} / \mathrm{mL}$. The same derivatives exhibited also a considerable antioxidant potency in scavenging tests (DPPH, ABTS, hydroxyl, nitric oxide, and superoxide). In the series, compounds possessing electron-donating substituents at the para position of the phenyl ring showed better radical scavenging effects compared to those possessing electron-withdrawing halogen atoms, despite a decreased antibacterial potency $(\mathbf{5 c})$.

\subsection{Isatin-thiosemicarbazones}

Thiosemicarbazones possess various biological activities, including antitubercolosis, antimicrobial, antibacterial, anticancer, antifungal, and antioxidant [135-141]. Thiosemicarbazonecompounds with an isatin moiety display also other types of biological properties, such as antiviral, antibacterial, anticancer, anticonvulsant and antidepressant activity [142-144]. As an example, methisazone was described as one of the first clinically used synthetic antiviral agent for treatment of smallpox [140]. Moreover, thiosemicarbazone derivatives containing monosaccharide moieties have shown a remarkable antimicrobial and antioxidant activities both in vivo and in vitro [140,141]. According to this, a new class of thiosemicarbazones containing simultaneously monosaccharide and isatin moieties has been reported [145] and evaluated against in vitro antibacterial and in vivo antioxidant activities (Fig. 13). For Gram-positive bacteria (B. subtilis, S. aureus and S. epidermidis), thiosemicarbazones with halogen substituents had the higher inhibition ability with MIC range values of $1.56-6.25 \mu \mathrm{g} /$ $\mathrm{mL}$ (6a). For Gram-negative bacteria instead (Enterobacter spp., E. coli, $P$. aeruginosa and $K$. pneumonia), derivatives having alkyl substituents at the $N$-position exhibited the strongest activity ( $\mathrm{MIC}=12.5 \mu \mathrm{g} / \mathrm{mL}, \mathbf{6 b}$ ). In the in vivo antioxidant assays, most of the compounds of the library displayed an extremely considerable activity, higher than the standard resveratrol, showing a significant elevation of free radical scavenging enzyme activities such as superoxide dismutases (SOD), catalase and glutathione peroxidase.

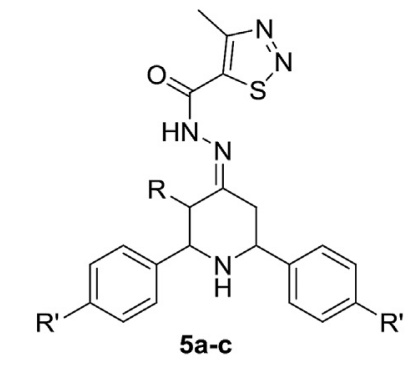

$\mathrm{R}=\mathrm{CH}_{3}(\mathbf{5 a}), \mathrm{CH}_{2} \mathrm{CH}_{3}(\mathbf{5 b}-\mathbf{5 c})$

$\mathrm{R}^{\prime}=\mathrm{F}(\mathbf{5 a}-\mathbf{b}), \mathrm{OCH}_{3}(\mathbf{5 c})$

MIC range 3.12-6.25 $\mu \mathrm{g} / \mathrm{mL}$ (5a), $6.25-25 \mu \mathrm{g} / \mathrm{mL}$ (5b), $50-100 \mu \mathrm{g} / \mathrm{mL}$ (5c)

DPPH IC ${ }_{50} 11.82 \mu \mathrm{g} / \mathrm{mL}(\mathbf{5 a}), 12.87 \mu \mathrm{g} / \mathrm{mL}(\mathbf{5 b}), 3.03 \mu \mathrm{g} / \mathrm{mL}(\mathbf{5 c})$

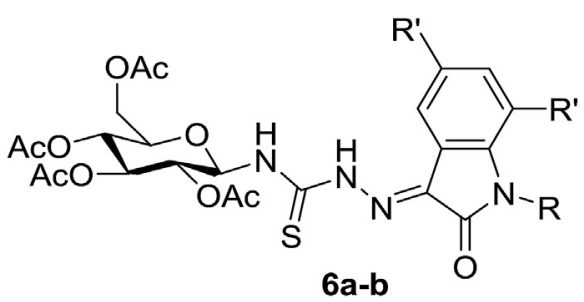

$\mathrm{R}=\mathrm{H}(\mathbf{6 a}), \mathrm{n}-\mathrm{Bu}(\mathbf{6 b})$
$\mathrm{R}^{\prime}=\mathrm{Br}(\mathbf{6 a}), \mathrm{H}(\mathbf{6 b})$
MIC Gram neg. $12.5 \mu \mathrm{g} / \mathrm{mL}(\mathbf{6 b})$
MIC Gram pos. $1.56 \mu \mathrm{g} / \mathrm{mL}(\mathbf{6 a})$
SOD 10.89 unit/mg protein (6a), $9.89 \mathrm{unit} / \mathrm{mg}$ protein $(\mathbf{6 b})$

Fig. 13. Dual active isatin-thiosemicarbazones.

\subsection{Barbiturates}

Barbiturates and thiobarbiturates are well-known compounds since the commercialization of benzodiazepines in the 1960s [146], but more recently this class of compounds attracted attention to medicinal chemists due to the discovery of a wide panel of biological activities as enzyme inhibitors (xanthine oxidase), as well as antibacterial, anticancer, antiangiogenic, antifungal, and antioxidant agents [147-152], most of them associated to several structural changes at diverse positions. Therefore, in search for new active compounds with these scaffolds, it was described the synthesis and the in vitro biological evaluation of some new 1,3,5trisubstituted barbiturates and thiobarbiturates where position 5 was functionalized with methylene, benzylidene and methyl moieties [153] (Fig. 14). These very recent derivatives were evaluated as xanthine oxidase inhibitors, as antibacterial agents against several Gram-positive and Gram-negative strains and as antioxidant compounds in standard DPPH radical scavenging tests. Among these, 5-hydrazinylethylidenepyrimidines showed a radical scavenging ability superior to the one observed with Trolox (7a-b). In addition, these pyrimidines exhibited a relevant and selective antibacterial activity, (in particular molecule $\mathbf{7 b}$ bearing a $p$-nitrophenyl moiety bound to the hydrazine group), against $A$. baumannii, a carbapenem-resistant Gram-negative bacteria pointed out from the World Health Organization as one of the critical pathogens in priority list for the development of new antibacterial agents [154].

\subsection{Indolophanes and 3-substituted indoles}

It is well known that the indole moiety is a bioactive nucleus present in diverse natural products [155,156]. Even if indole-based cyclophanes are not so frequently reported [157], these systems are encountering attention during recent times due to their biological applications. Furthermore, $\mathrm{N}$-arylindoles represent an important class of pharmacophores with a wide variety of bioactivities, such as antiestrogenic, analgesic, antiallergy, cyclooxygenase (COX)-1<smiles>[R]NNC(C)=C1C(=O)N(C)C(=O)N(C)C1=O</smiles>

$\mathrm{R}=\mathrm{C}_{6} \mathrm{H}_{5}(\mathbf{7 a}), 4-\mathrm{NO}_{2} \mathrm{C}_{6} \mathrm{H}_{4}(\mathbf{7 b})$

A. baumannii MIC $25 \mathrm{mg} / \mathrm{mL}$ (7a), $12.5 \mathrm{mg} / \mathrm{mL}$ (7b)

DPPH IC ${ }_{50} 22.6$ scav. eff. (7a), 23.9 scav. eff. (7b)

Fig. 12. Dual-active piperidone-hydrazides.

Fig. 14. Dual active barbiturates. 
inhibitory, and anti-HIV-1 activity [158-162]. Rajakumar et al. reported in 2014 some novel ethylenophanes which were tested for in vitro antioxidant and antibacterial activities [163]. Among these compounds, a derivative in particular (8) exhibited antibacterial versus Gram-positive and Gram-negative, and antioxidant properties similar to that of reference compounds such as streptomycin and ascorbic acid respectively (Fig. 15), resulting in a potential lead for the development of drugs with an interesting dual-activity.

A recent work by Sharma et al. [164] reported on the in vitro antioxidant, antibacterial, and antibiofilm properties of combined molecules including indole and 2-naphthol scaffolds. A series of diverse 3-naphthylindoles was obtained and most of the derivatives showed strong antioxidant properties in DPPH scavenging tests and an interesting antibacterial activity against common bacterial pathogens. Two of the more potent compounds exhibiting a potent dual-activity (9a-b) are reported in Fig. 15.

\subsection{Triazoles}

Even though 1,2,3-triazoles are not found in nature, there is evidence that synthetic molecules based on this moiety exhibited various biological activities, such as antifungal [165], antimicrobial [166], antiviral [167], and anti-tuberculosis [168]. Very recently, a series of new triazole-chalcones was obtained and further functionalized at the unsaturated carbonyl segment into various heterocyclic compounds as isoxazolines, pyrazoles, pyrimidines, and cyanopyridines [169]. The novel derivatives were screened for the antibacterial activity against Pseudomonas aeruginosa, E. coli, S. aureus and Bacillus subtilis and assayed in DPPH radical scavenging tests for evaluating the antioxidant potency. Within the modified compounds, only that presenting a pyrimidine (10) scaffold showed a discrete dual-activity, in particular, it disclosed a promising free radical scavenging ability and a good antibacterial activity, more potent towards Gram-positive bacteria i.e. Bacillus subtilis (Fig. 16).

In another recent work, Srinivas et al. [170] designed some 1,4disubstituted 1,2,3-triazoles combined with a $2 \mathrm{H}$-chromene-3tetrazole scaffold (Fig. 16, 11). $2 \mathrm{H}$-chromene system occupies a unique position in natural and synthetic compounds, for the antimicrobial [171], anti-inflammatory [172], antimalarial [173], and anticancer properties [174]. The novel $2 \mathrm{H}$-chromene-3-tetrazole derivatives were screened for in vitro antioxidant activity using DPPH radical, $\mathrm{H}_{2} \mathrm{O}_{2}$ scavenging, and iron chelating methods and also evaluated for in vitro antibacterial activities against $E$. coli and S. aureus bacterial strains. From the biological assays, compound $\mathbf{1 1}$ having unsubstituted benzyl group in the triazole fragment emerged for its potent antibacterial activity with a MIC value lower than the standard Ciprofloxacin and a considerable DPPH radical scavenging activity (Fig. 16).
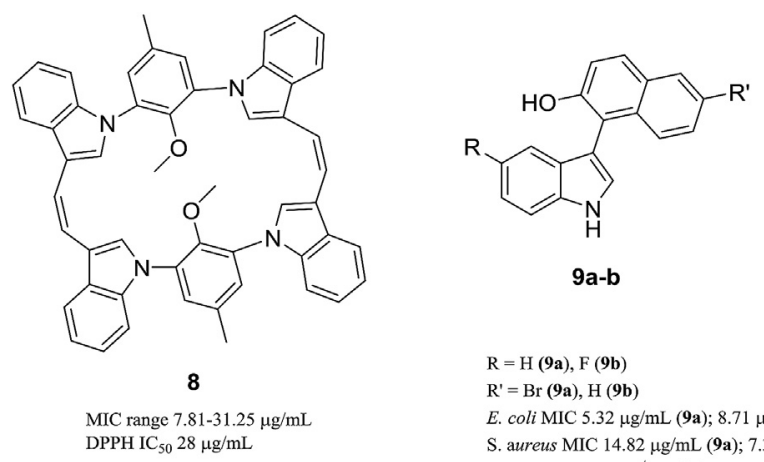

$\mathbf{R}=\mathrm{H}(\mathbf{9 a}), \mathbf{F}(\mathbf{9 b})$

$\mathrm{R}^{\prime}=\mathrm{Br}(9 \mathrm{a}), \mathrm{H}(9 \mathrm{~b})$

E. coli MIC $5.32 \mu \mathrm{g} / \mathrm{mL}(9 \mathrm{a}) ; 8.71 \mu \mathrm{g} / \mathrm{mL}(9 \mathrm{~b})$

S. aureus MIC $14.82 \mu \mathrm{g} / \mathrm{mL}(9 \mathrm{a}) ; 7.32 \mu \mathrm{g} / \mathrm{mL}(9 \mathrm{~b})$

$\mathrm{DPPH} \mathrm{EC}_{50} 3.80 \mu \mathrm{g}^{\prime} \mathrm{mL}(9 \mathrm{a}) ; 3.0 \mu \mathrm{g} / \mathrm{mL}(9 \mathrm{~b})$
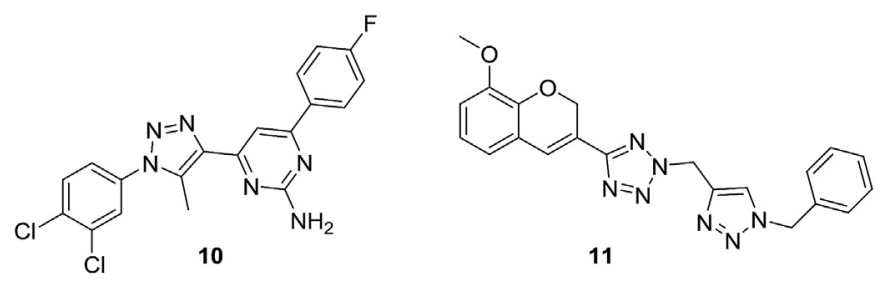

B. subtilis MIC $80.53 \mathrm{mM}$ $\mathrm{DPPH} \mathrm{IC}_{50} 59.07 \mu \mathrm{g} / \mathrm{mL}$

E. coli MIC $9.5 \mu \mathrm{g} / \mathrm{mL}$

S. aureus MIC $10.5 \mu \mathrm{g} / \mathrm{mL}$ DPPH IC $5078.74 \mu \mathrm{g} / \mathrm{mL}$

Fig. 16. Dual active triazoles.

\section{Conclusions}

The continued emergence of single and multiple antibioticresistant bacterial strains is one of the most important societal issues today. With the globally escalating incidence of multi-drugs infections, especially those caused by methicillin- and carbapenem-resistant superbugs, there is a need to restock our antibiotic arsenal and stay ahead of these pathogens.

It was reported that oxidative stress could contribute to the selection of resistant bacterial strains, since ROS revealed to be an essential driving force [3-5], even if the involvement of oxidative stress in the mechanism of antibiotic-mediated cell death is unclear and subject to debate [6]. In this context, molecules that combine two activities in the same structure, the antibacterial and the antioxidant, could be a possible answer to the urgent need for new antibacterial agents.

Structural diversity is a striking feature of natural products accounting for their lasting importance in drug discovery. Several plant-derived products, especially the class of phenols or polyphenols, show the two coupled antibacterial and antioxidant activities. Despite a high level of antioxidant potency, the antibacterial activity is sometimes modest; nevertheless, synergistic effects were observed when some natural phenols were associated with common antimicrobial drugs thus exhibiting an improved antibacterial activity. Moreover, the potentiating capacity of some natural compounds due to the anti-biofilm effect could also contribute in eradicating bacterial colonies. These properties could markedly take part in diminishing virulence for bacterial contamination or detrimental oxidative effects of materials and aqueous solutions in several fields such as the medical, food, and cosmetic industries.

Close to natural products, some selected examples of new compounds obtained by design and synthesis with an in-built capacity to act as antioxidants and antibacterials were reported. Some molecules present a combination of two pharmacophores built on the same structure which account for both the activities, as in the case of monocyclic beta-lactams bearing on a side chain a natural polyphenol moiety. This approach led to the development of molecular hybrids by fusing different biologically active agents into one molecule with the hope of retaining the biological actions of the constituent fragments [175]. The hypothesis of dual-active hybrids integrates the working concept of suppressing drug resistance evolution by presenting a molecular agent (instead of two) with a single pharmacokinetic profile. Moreover the integration of two pharmacophores in one molecule to get dual active agents may enhance the efficacy or even impart a new mechanism of action to the resulting hybrid agent. Hybridization of synthetic scaffolds with natural antioxidant components for generating new active molecules might be the future of antibacterial drug discovery combating drug-resistant pathogens.

Fig. 15. Dual active indolophanes and 3-naphtylindoles. 


\section{Acknowledgements}

The authors would like to thank the University of Bologna (RFO 2017), and the Italian Cystic Fibrosis Foundation, for a past funding grant FFC \# 11/2011 which inspired us.

\section{References}

[1] World Health Organization (WHO), Global Action Plan on Antimicrobial Resistance, 2015. http://www.who.int/antimicrobial-resistance/ globalaction-plan/en/.

[2] European commission, A European One Health Action Plan against Antimicrobial Resistance (AMR), 2017. http://ec.europa.eu/health/amr/action_eu en.

[3] O.H. Aragon-Martinez, F. Martinez-Morales, M.A. Isiordia-Espinoza, D. Luque Contreras, J.R. Zapata Morales, M.L. Gonzalez-Rivera, Bacterial resistance and failure of clinical cure could be produced by oxidative stress in patients with diabetes or cardiovascular diseases during fluoroquinolone therapy, Med. Hypotheses 103 (2017) 32-34, https://doi.org/10.1016/j.mehy.2017.04.004.

[4] S.L. Chua, Y. Ding, Y. Liu, Z. Cai, J. Zhou, S. Swarup, D.I. Drautz-Moses, S.C. Schuster, S. Kjelleberg, M. Givskov, L. Yang, Reactive oxygen species drive evolution of pro-biofilm variants in pathogens by modulating cyclic-di-GMP levels, Open Biol 6 (2016) 160-162, https://doi.org/10.1098/rsob.160162.

[5] S.S. Grant, D.T. Hung, Persistent bacterial infections, antibiotic tolerance, and the oxidative stress response, Virulence 4 (2013) 273-283, https://doi.org/ $10.4161 /$ viru. 23987.

[6] G. Smirnova, N. Muzyka, E. Lepekhina, O. Oktyabrsky, Roles of the glutathione- and thioredoxin-dependent systems in the Escherichia coli responses to ciprofloxacin and ampicillin, Arch. Microbiol. 198 (2016) 913-921, https://doi.org/10.1007/s00203-016-1247-z.

[7] M.A. Kohanski, D.J. Dwyer, B. Hayete, C.A. Lawrence, J. Collins, A common mechanism of cellular death induced by bactericidal antibiotics, Cell 130 (2007) 797-810, https://doi.org/10.1016/j.cell.2007.06.049.

[8] H. Van Acker, T. Coenye, The role of reactive oxygen species in antibioticmediated killing of bacteria, Trends Microbiol. 25 (2017) 456-466, https:// doi.org/10.1016/j.tim.2016.12.008.

[9] I. Keren, Y. Wu, J. Inocencio, L.R. Mulcahy, K. Lewis, Killing by bactericidal antibiotics does not depend on reactive oxygen species, Science 339 (2013) 1213-1216, https://doi.org/10.1126/science.1232688.

[10] Y. Liu, J. Imlay, A. Cell, Death from antibiotics without the involvement of reactive oxygen species, Science 339 (2013) 1210-1213, https://doi.org/ 10.4155/fmc-2016-0223.

[11] D.J. Dwyer, M.A. Kohanski, J.J. Collins, Role of reactive oxygen species in antibiotic action and resistance, Curr. Opin. Microbiol. 12 (2009) 482-489, https://doi.org/10.1016/j.mib.2009.06.018.

[12] M. Valko, D. Leibfritz, J. Moncola, M.T.D. Cronin, M. Mazura, J. Telser, Free radicals and antioxidants in normal physiological functions and human disease, Int. J. Biochem. Cell Biol. 39 (2007) 44-84, https://doi.org/10.1016/ j.biocel.2006.07.001.

[13] A. Hector, M. Griese, D. Hartl, Oxidative stress in cystic fibrosis lung disease: an early event, but worth targeting, Eur. Respir. J. 44 (2014) 17-19, https:// doi.org/10.1183/09031936.00038114.

[14] F. Galli, A. Battistoni, R. Gambari, A. Pompella, A. Bragonzi, F. Pilolli, L. Iuliano, M. Piroddi, M.C. Dechecchi, G. Cabrini, Oxidative stress and antioxidant therapy in cystic fibrosis, Biochim. Biophys. Acta 1822 (2012) 690-713. https://doi.org/10.1016/j.bbadis.2011.12.012.

[15] V. Vaillant, H. De Valk, E. Baron, T. Ancelle, P. Colin, M.C. Delmas, B. Dufour, R. Pouillot, Y. Le Strat, P. Weinbrec, E. Jougla, J.C. Desenclos, Foodborne infections in France, Foodb. Pathog. Dis. 2 (2005) 221-232, https://doi.org/ 10.1089/fpd.2005.2.221.

[16] H.-J. Suh, M.-S. Chung, Y.-H. Cho, J.-W. Kim, D.-H. Kim, K.-W. Han, C.-J. Kim, Estimated daily intakes of butylated hydroxyanisole (BHA), butylated hydroxytoluene (BHT) and tert-butyl hydroquinone (TBHQ) antioxidants in Korea, Food Addit. Contam. 22 (2005) 1176-1188, https://doi.org/10.1080/ 02652030500195288

[17] D.J. Newman, G.M. Cragg, Natural products as sources of new drugs from 1981 to 2014, J. Nat. Prod. 79 (2016) 629-661, https://doi.org/10.1021/ acs.jnatprod.5b01055.

[18] S.E. Rossiter, M.H. Fletcher, W.M. Wuest, Natural products as platforms to overcome antibiotic resistance, Chem. Rev. 117 (2017) 12415-12474, https://doi.org/10.1021/acs.chemrev.7b00283.

[19] L.N. Silva, K. Rigon Zimmer, A.J. Macedo, D.S. Trentin, Plant natural products targeting bacterial virulence factors, Chem. Rev. 116 (2016) 9162-9236, https://doi.org/10.1021/acs.chemrev.6b00184.

[20] Y. Xi, G.A. Sullivan, A.L. Jackson, G.H. Zhou, J. Sebranek, G, Use of natural antimicrobials to improve the control of Listeria monocytogenes in a cured cooked meat model system, Meat Sci. 88 (2011) 503-511, https://doi.org/ 10.1016/j.meatsci.2011.01.036.

[21] J.L. Guil-Guerrero, L. Ramos, C. Moreno, J.C. Zúñiga-Paredes, M. CarlosamaYepez, P. Ruales, Antimicrobial activity of plant-food by-products: a review focusing on the tropics, Livest. Sci. 189 (2016) 32-49.

[22] R. Gyawali, S.A. Ibrahim, Natural products as antimicrobial agents, Food
Contr. 46 (2014) 412-429.

[23] H. Wagner, Synergy research: approaching a new generation of phytopharmaceuticals, Fitoterapia 82 (2011) 34-37, https://doi.org/10.1016/ j.fitote.2010.11.016.

[24] S.A. Zacchino, E. Butassi, E. Cordisco, L.A. Svetaz, Hybrid combinations containing natural products and antimicrobial drugs that interfere with bacterial and fungal biofilms, Phytomedicine 37 (2017) 14-26, https://doi.org/ 10.1016/j.phymed.2017.10.021

[25] S.A. Zacchino, E. Butassi, M. Di Liberto, M. Raimondi, A. Postigo, M. Sortino Plant phenolics and terpenoids as adjuvants of antibacterial and antifungal drugs, Phytomedicine 37 (2017) 27-48, https://doi.org/10.1016/ j.phymed.2017.10.018.

[26] H. Dorman, S. Deans, Antimicrobial agents from plants: antibacterial activity of plant volatile oils, J. Appl. Microbiol. 88 (2000) 308-316, https://doi.org/ 10.1046/j.1365-2672.2000.00969.x.

[27] J.R. Calo, P.G. Crandall, C.A. O'Bryan, S.C. Ricke, Essential oils as antimicrobials in food systems. A review, Food Contr. 54 (2015) 111-119, https://doi.org/ 10.1016/j.foodcont.2014.12.040.

[28] R. Amorati, M.C. Foti, L. Valgimigli, Antioxidant activity of essential oils, J. Agric. Food Chem. 61 (2013) 10835-10847, https://doi.org/10.1021/ jf403496k.

[29] S.-K. Yang, L.-Y. Low, P.S.-X. Yap, K. Yusoff, C.-W. Mai, K.-S. Lai, S.-H.E. Lim, Plant-derived antimicrobials: insights into mitigation of antimicrobial resistance, Record Nat. Prod. 12 (2018) 295-316, https://doi.org/10.25135 rnp.41.17.09.058

[30] P.S.X. Yap, B.C. Yiap, H.C. Ping, S.H.E. Lim, Essential oils, a new horizon in combating bacterial antibiotic resistance, Open Microbiol. J. 8 (2014) 6-14, https://doi.org/10.2174/1874285801408010006

[31] D. Stojković, J. Petrović, M. Soković, J. Glamoĉlija, J. Kukić-Marković, S. Petrović, In situ antioxidant and antimicrobial activities of naturally occurring caffeic acid, p-coumaric acid and rutin, using food systems, J. Sci. Food Agric. 93 (2013) 3205-3208, https://doi.org/10.1002/jsfa.6156.

[32] M. Nazck, F. Shahidi, Phenolics in cereals, fruits and vegetables: occurrence, extraction and analysis, J. Pharmaceut. Biomed. Anal. 41 (2006) 1523-1542, https://doi.org/10.1016/j.jpba.2006.04.002.

[33] R.J. Lambert, P.N. Skandamis, P.J. Coote, G.J. Nychas, A study of the minimum inhibitory concentration and mode of action of oregano essential oil, thymo and carvacrol, J. Appl. Microbiol. 91 (2001) 453-462, https://doi.org/ 10.1046/j.1365-2672.2001.01428.x.

[34] K. Palaniappan, R.A. Holley, Use of natural antimicrobials to increase antibiotic susceptibility of drug resistant bacteria, Int. J. Food Microbiol. 140 (2010) 164-168, https://doi.org/10.1016/j.ijfoodmicro.2010.04.001.

[35] J.D. Rajput, S.D. Bagul, U.D. Pete, C.M. Zade, S.B. Padhye, R.S. Bendre, Perspectives on medicinal properties of natural phenolic monoterpenoids and their hybrids, Mol. Divers. 22 (2018) 225-245, https://doi.org/10.1007/ s11030-017-9787-y.

[36] N. Martins, L. Barros, I.C.F.R. Ferreira, In vivo antioxidant activity of phenolic compounds: facts and gaps, Trends Food Sci. Technol. 48 (2016) 1-12, https://doi.org/10.1016/j.tifs.2015.11.008.

[37] B. Holst, G. Williamson, Nutrients and phytochemicals: from bioavailability to bioefficacy beyond antioxidants, Curr. Opin. Biotechnol. 19 (2008) 73-82. https://doi.org/10.1016/j.copbio.2008.03.003.

[38] J. Dai, R.J. Mumper, Plant phenolics: extraction, analysis and, their antioxidant and anticancer properties, Molecules 15 (2010) 7313-7352, https:/ doi.org/10.3390/molecules15107313.

[39] N.B. Shelke, R. James, C.T. Laurencin, S.G. Kumbar, Polysaccharide biomaterials for drug delivery and regenerative engineering, Polym. Adv. Technol. 25 (2014) 448-460, https://doi.org/10.1002/pat.3266.

[40] H. Liu, B. Lepoittevin, C. Roddier, V. Guerineau, L. Bech, J.M. Herry, M.N. Bellon-Fontaine, P. Roger, Facile synthesis and promising antibacteria properties of a new guaiacol-based polymer, Polymer 52 (2011) 1908-1916 https://doi.org/10.1016/j.polymer.2011.02.046.

[41] M.-C. Kouassi, P. Thébault, C. Rihouey, E. Dé, B. Labat, L. Picton, V. Dulong, Carboxymethylpullulan grafted with aminoguaiacol: synthesis, characterization, and assessment of antibacterial and antioxidant properties, Biomacromolecules 18 (2017) 3238-3251, https://doi.org/10.1021/ acs.biomac.7b00899.

[42] E.Y. Plotnikov, M.A. Morosanova, I.B. Pevzner, L.D. Zorova, V.N. Manskikh, N.V. Pulkova, S.I. Galkina, V.P. Skulachev, D.B. Zorov, Protective effect of mitochondria-targeted antioxidants in an acute bacterial infection, P. Natl. Akad. Sci. USA (2013) E3100-E3108, https://doi.org/10.1073/ pnas.1307096110.

[43] P.A. Nazarov, I.A. Osterman, A.V. Tokarchuk, M.V. Karakozova, G.A. Korshunova, K.G. Lyamzaev, M.V. Skulachev, E.A. Kotova, V.P. Skulachev, Y.N. Antonenko, Mitochondria-targeted antioxidants as highly effective antibiotics, Sci. Rep. 7 (2017) 1394, https://doi.org/10.1038/s41598-01700802-8.

[44] J. Sun, M.-H. Li, X.-Y. Wang, Y. Zhang, R.-J. Yuan, H.-Y. Liu, H.-L. Zhu, Vanillin derivatives as the selective small molecule inhibitors of FtsZ, Med. Chem. Res. 23 (2014) 2985-2994, https://doi.org/10.1007/s00044-013-0886-8.

[45] S.T. Harini, H.V. Kumar, J. Rangaswamy, N. Naik, Synthesis, antioxidant and antimicrobial activity of novel vanillin derived piperidin-4-one oxime esters: preponderant role of the phenyl ester substituents on the piperidin-4-one oxime core, Bioorg. Med. Chem. Lett 22 (2012) 7588-7592, https://doi.org/ 10.1016/j.bmcl.2012.10.019. 
[46] C.F. Bezerra, C.J. Camilo, M.K. do Nascimento Silva, T.S. de Freitas, J. RibeiroFilho, H.D. Melo Coutinho, Vanillin selectively modulates the action of antibiotics against resistant bacteria, Microb. Pathog. 113 (2017) 265-268, https://doi.org/10.1016/j.micpath.2017.10.052.

[47] V. Filip, M. Plocková, J. Šmidrkal, Z. Špiĉková, K. Melzoch, Š. Schmidt, Resveratrol and its antioxidant and antimicrobial effectiveness, Food Chem. 83 (2003) 585-593, https://doi.org/10.1016/S0308-8146(03)00157-2.

[48] I. Ahuja, R. Kissen, A.M. Bones, Phytoalexins in defense against pathogens, Trends Plant Sci. 17 (2012) 73-90, https://doi.org/10.1016/ j.tplants.2011.11.002.

[49] P. Rodríguez-Bonilla, F. Gandía-Herrero, A. Matencio, F. García-Carmona, J.M. López-Nicolás, Comparative study of the antioxidant capacity of four stilbenes using ORAC, ABTS+, and FRAP techniques, Food Anal. Methods 10 (2017) 2994-3000, https://doi.org/10.1007/s12161-017-0871-9.

[50] D.S.L. Ma, L.T.-H. Tan, K.-G. Chan, W.H. Yap, P. Pusparajah, L.-H. Chuah, L.C. Ming, T.M. Khan, L.H. Lee, B.H. Goh, Resveratrol-potential antibacteria agent against foodborne pathogens, Front. Pharmacol. 9 (2018) 102, https:/ doi.org/10.3389/fphar.2018.00102.

[51] L. Paulo, S. Ferreira, E. Gallardo, J.A. Queiroz, F. Domingues, Antimicrobial activity and effects of resveratrol on human pathogenic bacteria, World J. Microbiol. Biotechnol. 26 (2010) 1533-1538, https://doi.org/10.1007/ s11274-010-0325-7.

[52] S.N. Kumar, J.V. Siji, B. Nambisan, C. Mohandas, Activity and synergistic interactions of stilbenes and antibiotic combinations against bacteria in vitro, World J. Microbiol. Biotechnol. 28 (2012) 3143-3150, https://doi.org/ 10.1007/s11274-012-1124-0.

[53] M. Subramanian, M. Goswami, S. Chakraborty, N. Jawali, Resveratrol induced inhibition of Escherichia coli proceeds via membrane oxidation and independent of diffusible reactive oxygen species generation, Redox Biol 2 (2014) 865-872, https://doi.org/10.1016/j.redox.2014.06.007.

[54] M. Subramanian, S. Soundar, S. Mangoli, DNA damage is a late event in resveratrol-mediated inhibition of Escherichia coli, Free Radic. Res. 50 (2016) 708-719, https://doi.org/10.3109/10715762.2016.1169404.

[55] M.G. Tosato, P.L. Schilardi, M.F.L. de Mele, A.H. Thomas, A. Miñán, C. Lorente, Resveratrol enhancement staphylococcus aureus survival under levofloxacin and photodynamic treatments, Int. J. Antimicrob. Agents 51 (2018) 255-259, https://doi.org/10.1016/j.ijantimicag.2017.10.006.

[56] Y. Liu, J. Zhou, Y. Qu, X. Yang, G. Shi, X. Wang, Y. Hong, K. Drlica, X. Zhao, Resveratrol antagonizes antimicrobial lethality and stimulates recovery of bacterial mutants, PLoS One 11 (2016), https://doi.org/10.1371/journal.pone.0153023 e0153023.

[57] J.-W. Zhou, T.-T. Chen, X.-J. Tan, J.-Y. Sheng, A.-Q. Jia, Can resveratrol, a quorum sensing inhibitor, function as an aminoglycoside antibioticaccelerant against Pseudomonas aeruginosa? Int. J. Antimicrob. Agents (2018) https://doi.org/10.1016/j.ijantimicag.2018.03.002.

[58] A.M. Pisoschi, A. Pop, C. Georgescu, V. Turcuş, N.K. Olah, E. Mathe, An overview of natural antimicrobials role in food, Eur. J. Med. Chem. 143 (2018) 922-935, https://doi.org/10.1016/j.ejmech.2017.11.095.

[59] A. Morán, S. Gutiérrez, H. Martínez-Blanco, M.A. Ferrero, A. MonteagudoMera, L.B. Rodríguez-Aparicio, Non-toxic plant metabolites regulate Staphylococcus viability and biofilm formation: a natural therapeutic strategy useful in the treatment and prevention of skin infections, Biofouling 30 (2014) 1175-1182, https://doi.org/10.1080/08927014.2014.976207.

[60] N. Qin, X. Tan, Y. Jiao, L. Liu, W. Zhao, S. Yang, A. Jia, RNA-Seq-based transcriptome analysis of methicillin-resistant Staphylococcus aureus biofilm inhibition by ursolic acid and resveratrol, Sci. Rep. 4 (2014) 5467, https:/ doi.org/10.1038/srep05467.

[61] S. Ferreira, F. Domingues, The antimicrobial action of resveratrol against Listeria monocytogenes in food-based models and its antibiofilm properties, J. Sci. Food Agric. 96 (2016) 4531-4535, https://doi.org/10.1002/jsfa.7669.

[62] J.-H. Lee, H.S. Cho, S.W. Joo, S. Chandra Regmi, J.-A. Kim, C.-M. Ryu, S.Y. Ryu, M.H. Cho, J. Lee, Diverse plant extracts and trans-resveratrol inhibit biofilm formation and swarming of Escherichia coli 0157:H7, Biofouling 29 (2013) 1189-1203, https://doi.org/10.1080/08927014.2013.832223.

[63] A. Duarte, A.C. Alves, S. Ferreira, F. Silva, F.C. Domingues, Resveratrol inclusion complexes: antibacterial and anti-biofilm activity against Campylobacter spp. and Arcobacter butzleri, Food Res. Int. 77 (2015) 244-250 https://doi.org/10.1016/j.foodres.2015.05.047.

[64] N. Augustine, A.K. Goel, K.C. Sivakumar, R.A. Kumar, S. Thomas, Resveratrol-a potential inhibitor of biofilm formation in vibrio cholera, Phytomedicine $21 \quad$ (2014) 286-289, https://doi.org/10.1016/ j.phymed.2013.09.010

[65] S.J. Hewlings, D.S. Kalman, Curcumin: a review of its' effects on human health, Foods 6 (2017) 92, https://doi.org/10.3390/foods6100092.

[66] A.B. Kunnumakkara, D. Bordoloi, G. Padmavathi, J. Monisha, N.K. Roy, S. Prasad, B.B. Aggarwal, Curcumin, the golden nutraceutical: multitargeting for multiple chronic diseases, Br. J. Pharmacol. 174 (2017) 1325-1348, https://doi.org/10.1111/bph.13621.

[67] L. Arshad, M.A. Haque, S.N.A. Bukhari, I. Jantan, An overview of structure-activity relationship studies of curcumin analogs as antioxidant and anti-inflammatory agents, Future Med. Chem. 9 (2017) 605-626, https://doi.org/10.4155/fmc-2016-0223.

[68] T. Ak, I. Gülçin, Antioxidant and radical scavenging properties of curcumin, Chem. Biol. Interact. 74 (2008) 27-37, https://doi.org/10.1016/ j.cbi.2008.05.003.
[69] D.S.H.L. Kim, S.-Y. Park, J.-Y. Kim, Curcuminoids from curcuma longa 1. (zingiberaceae) that protect pc12 rat pheochromocytoma and normal human umbilical vein endothelial cells from $\beta \mathrm{A}(1-42)$ insult, Neurosci. Lett. 303 (2001) 57-61, https://doi.org/10.1016/S0304-3940(01)01677-9.

[70] S.-Y. Teow, K. Liew, S.A. Ali, A.S.-B. Khoo, S.-C. Peh, Antibacterial action of curcumin against Staphylococcus aureus: a brief review, J. Trop. Med. (2016) 2853045, https://doi.org/10.1155/2016/2853045.

[71] A.R. Vaughn, K.N. Haas, W. Burney, E. Andersen, A.K. Clark, R. Crawford, R.K. Sivamani, Potential role of curcumin against biofilm-producing organisms on the skin: a review, Phytother Res. 31 (2017) 1807-1816, https:// doi.org/10.1002/ptr.5912.

[72] S. Kaur, N.H. Modi, D. Panda, N. Roy, Probing the binding site of curcumin in Escherichia coli and Bacillus subtilis FtsZ - a structural insight to unveil antibacterial activity of curcumin, Eur. J. Med. Chem. 45 (2010) 4209-4214, https://doi.org/10.1016/j.ejmech.2010.06.015.

[73] A.C da Silva, P.D de Freitas Santos, JT do Prado Silva, F.V. Leimann, L. Bracht, O.H. Gonçalves, Impact of curcumin nanoformulation on its antimicrobial activity, Trends Food Sci. Technol. 72 (2018) 74-82, https://doi.org/10.1016/ j.tifs.2017.12.004.

[74] J. Shaikh, D.D. Ankola, V. Beniwal, D. Singh, M.N.V. Ravi Kumar, Nanoparticle encapsulation improves oral bioavailability of curcumin by at least 9-fold when compared to curcumin administered with piperine as absorption enhancer, Eur. J. Pharmaceut. Sci. 37 (2009) 223-230, https://doi.org/ 10.1016/j.ejps.2009.02.019.

[75] E. Marini, M. Di Giulio, G. Magi, S. Di Lodovico, M.E. Cimarelli, A. Brenciani, A. Nostro, L. Cellini, B. Facinelli, Curcumin, an antibiotic resistance breaker against a multiresistant clinical isolate of Mycobacterium abscessus, Phytother Res. 32 (2018) 488-495, https://doi.org/10.1002/ptr.5994.

[76] G. Banuppriya, R. Sribalan, V. Padmini, Evaluation of antioxidant, antiinflammatory, antibacterial activity and in silico molecular docking study of pyrazole curcumin bisacetamide analogs, Chemistry 2 (2017) 9168-9173, https://doi.org/10.1002/slct.201701533.

[77] D.R. Emam, A.M. Alhajoj, K.M. Elattar, N.A. Kheder, A.A. Fadda, Synthesis and evaluation of curcuminoid analogues as antioxidant and antibacterial agents, Molecules 22 (2017) 971-980, https://doi.org/10.3390/molecules22060971.

[78] R. Shuab, R. Lone, K.K. Koul, Cinnamate and cinnamate derivatives in plants, Acta Physiol. Plant. 38 (2016) 64, https://doi.org/10.1007/s11738-016-2076-

[79] C. Mancuso, R. Santangelo, Ferulic acid: pharmacological and toxicological aspects, Food Chem. Toxicol. 65 (2014) 185-195, https://doi.org/10.1016/ j.fct.2013.12.024.

[80] N. Kumar, V. Pruthi, Potential applications of ferulic acid from natural sources, Biotechnol. Rep. 4 (2014) 86-93, https://doi.org/10.1016/ j.btre.2014.09.002.

[81] B. Ergün, T. Coban, F.K. Onurdag, E. Banoglu, Synthesis, antioxidant and antimicrobial evaluation of simple aromatic esters of ferulic acid, Arch Pharm. Res. (Seoul) 34 (2011) 1251-1261, https://doi.org/10.1007/s12272011-0803-y.

[82] J.D. Guzman, Natural cinnamic acids, synthetic derivatives and hybrids with antimicrobial activity, Molecules 19 (2014) 19292-19349, https://doi.org/ 10.3390/molecules191219292.

[83] M. Sova, Antioxidant and antimicrobial activities of cinnamic acid derivatives, Mini Rev. Med. Chem. 12 (2012) 749-767, https://doi.org/10.2174/ 138955712801264792.

[84] B. Yingyongnarongkul, N. Apiratikul, N. Aroonrerk, A. Suksamrarn, Solidphase synthesis and antibacterial activity of hydroxycinnamic acid amides and analogues against methicillin-resistant Staphylococcus aureus and vancomycin-resistant S. aureus, Bioorg. Med. Chem. Lett 16 (2006) 5870-5873, https://doi.org/10.1016/j.bmcl.2006.08.062.

[85] M. Matejczyk, R. Swisłocka, A. Golonko, W. Lewandowski, E. Hawrylik, Cytotoxic, genotoxic and antimicrobial activity of caffeic and rosmarinic acids and their lithium, sodium and potassium salts as potential anticancer compounds, Adv. Med. Sci. 63 (2018) 14-21, https://doi.org/10.1016/ j.advms.2017.07.003.

[86] T. Zhang, X. Wei, Z Miao, H. Hassan, Y Song, M. Fan, Screening for antioxidant and antibacterial activities of phenolics from Golden Delicious apple pomace, Chem. Cent. J. 10 (2016) 47, https://doi.org/10.1186/s13065-0160195-7.

[87] D.-S. Lee, J.-Y. Woo, C.-B. Ahn, J.-Y. Je, Chitosan-hydroxycinnamic acid conjugates: preparation, antioxidant and antimicrobial activity, Food Chem. 148 (2014) 97-104, https://doi.org/10.1016/j.foodchem.2013.10.019.

[88] M.N. Clifford, I.B. Jaganath, I.A. Ludwig, A. Crozier, Chlorogenic acids and the acyl-quinic acids: discovery, biosynthesis, bioavailability and bioactivity, Nat. Prod. Rep. 34 (2017) 1391-1421, https://doi.org/10.1039/c7np00030h.

[89] Y. Tošović, S. Marković, J. Dimitrić, M. Marković, M. Mojović, D. Milenković, Antioxidative mechanisms in chlorogenic acid, Food Chem. 237 (2017) 390-398, https://doi.org/10.1016/j.foodchem.2017.05.080.

[90] U.-H. Jin, J.-Y. Lee, S.-K. Kang, J.-K. Kim, W.-H. Park, J.-G. Kim, S.-K. Moon, C.$\mathrm{H}$. Kim, A phenolic compound, 5-caffeoylquinic acid (chlorogenic acid), is a new type and strong matrix metalloproteinase-9 inhibitor: isolation and identification from methanol extract of Euonymus alatus, Life Sci. 77 (2005) 2760-2769, https://doi.org/10.1016/j.lfs.2005.02.028.

[91] M. Naveed, V. Hejazi, M. Abbas, A.A. Kamboh, G.J. Khan, M. Shumzaid F. Ahmad, D. Babazadeh, X. Fang Fang, F. Modarresi-Ghazani, L.W. Hua, Z.X. Hui, Chlorogenic acid (CGA): a pharmacological review and call for 
further research, Biomed. Pharmacother. 97 (2018) 67-74, https://doi.org/ 10.1016/j.biopha.2017.10.064.

[92] Y.C. Fiamegos, P. L: Kastritis, V. Exarchou, H. Han, A.M.J.J. Bonvin, J. Vervoort, K. Lewis, M.R. Hamblin, G.P. Tegos, Antimicrobial and efflux pump inhibitory activity of caffeoylquinic acids from Artemisia absinthium against grampositive pathogenic bacteria, PLoS One 6 (2011), e18127, https://doi.org/ 10.1371/journal.pone.0018127.

[93] J. Gershenzon, N. Dudareva, The function of terpene natural products in the natural world, Nat. Chem. Biol. 3 (2007) 408-414, https://doi.org/10.1038/ nchembio.2007.5.

[94] H.O.B. Oloyede, H.O. Ajiboye, M.O. Salawu, T.O. Ajiboye, Influence of oxidative stress on the antibacterial activity of betulin, betulinic acid and ursolic acid, Microb. Pathog. 111 (2017) 338-344, https://doi.org/10.1016/ j.micpath.2017.08.012.

[95] B. D'Abrosca, A. Fiorentino, P. Monaco, S. Pacifico, Radical-scavenging activities of new hydroxylated ursane triterpenes from cv, Annurca Apples, Chem. Biodiv. 2 (2005) 953-958, https://doi.org/10.1002/cbdv.200590072.

[96] K. Wolska, A. Grudniak, B. Fiecek, A. Kraczkiewicz-Dowjat, A. Kurek, Antibacterial activity of oleanolic and ursolic acids and their derivatives, Open Life Sci. 5 (2010) 543-553, https://doi.org/10.2478/s11535-010-0045-x.

[97] P.G. do Nascimento, T.L. Lemos, A. Bizerra, Â. Arriaga, D.A. Ferreira, G.M. Santiago, R. Braz-Filho, J.G.M. Costa, Antibacterial and antioxidant activities of ursolic acid and derivatives, Molecules 19 (2014) 1317-1327. https://doi.org/10.3390/molecules19011317.

[98] A. Kurek, P. Nadkowska, S. Pliszka, K.I. Wolska, Modulation of antibiotic resistance in bacterial pathogens by oleanolic acid and ursolic acid, Phytomedicine $19 \quad$ (2012) 515-519, https://doi.org/10.1016/ j.phymed.2011.12.009.

[99] D. Singh, D.P. Pathak, Anjali, Coumarins: an overview of medicinal chemistry, Potential for New Drug Molecules, IJPSR 7 (2016) 482-504, https://doi.org/ 10.13040/IJPSR.0975-8232.7 (2).482-04.

[100] K.N. Venugopala, V. Rashmi, B. Odhav, Review on natural coumarin lead compounds for their pharmacological activity, BioMed Res. Int. (2013) 963248, https://doi.org/10.1155/2013/963248.

[101] P. Manojkumar, T.K. Ravi, S. Gopalakrishnan, Antioxidant and antibacterial studies of arylazopyrazoles and arylhydrazonopyrazolones containing coumarin moiety, Eur. J. Med. Chem. 44 (2009) 4690-4694, https://doi.org/ 10.1016/j.ejmech.2009.07.004

[102] N. Vukovic, S. Sukdolak, S. Solujic, N. Niciforovic, Substituted imino and amino derivatives of 4-hydroxycoumarins as novel antioxidant, antibacterial and antifungal agents: synthesis and in vitro assessments, Food Chem. 120 (2010) 1011-1018, https://doi.org/10.1016/j.foodchem.2009.11.040.

[103] J. Tian, L. Fu, Z. Zhang, X. Dong, D. Xu, Z. Mao, Y. Liu, D. Lai, L. Zhou, Dibenzo$\alpha$-pyrones from the endophytic fungus Alternaria sp. Samif01: isolation, structure elucidation, and their antibacterial and antioxidant activities, Nat. Prod. Res. 31 (2017) 387-396, https://doi.org/10.1080/ 14786419.2016.1205052.

[104] A. Idhayadhulla, L. Xia, Y.R. Lee, S.H. Kim, Y.-J. Wee, C.-S. Lee, Synthesis of novel and diverse mollugin analogues and their antibacterial and antioxidant activities, Bioorg. Chem. 52 (2014) 77-82, https://doi.org/10.1016/ j.bioorg.2013.11.008.

[105] L. Xia, A. Idhayadhulla, Y.R. Lee, S.H. Kim, Y.-J. Wee, Antioxidant and antibacterial evaluation of synthetic furomollugin and its diverse analogs, Med. Chem. Res. 23 (2014) 3528-3538, https://doi.org/10.1007/s00044-0140929-9.

[106] L. Xia, A. Idhayadhulla, Y.R. Lee, Y.-J. Wee, S.H. Kim, Anti-tyrosinase, antioxidant, and antibacterial activities of novel 5-hydroxy-4-acetyl-2,3dihydronaphtho[1,2-b]furans, Eur. J. Med. Chem. 86 (2014) 605-612, https://doi.org/10.1016/j.ejmech.2014.09.025.

[107] T. Bishop, P. Sham, Analysis of Multifactorial Diseases, Academic Press, New York, 2000 eBook ISBN: 9780080916927. Paperback ISBN: 9780121016104.

[108] A. Agis-Torres, M. Söllhuber, M. Fernandez, J.M. Sanchez-Montero, Multitarget-directed ligands and other therapeutic strategies in the search of a real solution for Alzheimer's disease, Curr. Neuropharmacol. 12 (2013) 2-36, https://doi.org/10.2174/1570159X113116660047.

[109] M.J. Oset-Gasque, J. Marco-Contelles, Alzheimer's disease, the "one-molecule, one-target" paradigm, and the multitarget directed ligand approach, ACS Chem. Neurosci. 9 (2018) 401-403, https://doi.org/10.1021/ acschemneuro.8b00069.

[110] A.G. Ziady, J. Hansen, Redox balance in cystic fibrosis, Int. J. Biochem. Cell Biol. 52 (2014) 113-123, https://doi.org/10.1016/j.biocel.2014.03.006.

[111] L. Spicuzza, G.F. Parisi, L. Tardino, N. Ciancio, R. Nenna, F. Midulla, S. Leonardi, Exhaled markers of antioxidant activity and oxidative stress in stable cystic fibrosis patients with moderate lung disease, J. Breath Res. 12 (2018), 026010, https://doi.org/10.1088/1752-7163/aa9b39.

[112] P. Galletti, C.E.A. Cocuzza, M. Pori, A. Quintavalla, R. Musumeci, D. Giacomini, Antibacterial agents and cystic fibrosis: synthesis and antimicrobial evaluation of a series of $N$-thiomethyl azetidinones, ChemMedChem 6 (2011) 1919-1927, https://doi.org/10.1002/cmdc.201100282.

[113] G. Cainelli, C. Angeloni, R. Cervellati, P. Galletti, D. Giacomini, S. Hrelia, R. Sinisi, New polyphenolic $\beta$-lactams with antioxidant activity, Chem. Biodivers. 5 (2008) 811-829, https://doi.org/10.1002/cbdv.200890077.

[114] R. Cervellati, P. Galletti, E. Greco, C.E.A. Cocuzza, R. Musumeci, L. Bardini, F. Paolucci, M. Pori, R. Soldati, D. Giacomini, Monocyclic $\beta$-lactams as antibacterial agents: facing antioxidant activity of $\mathrm{N}$-methylthio-azetidinones,
Eur. J. Med. Chem. 60 (2013) 340-349, https://doi.org/10.1016/ j.ejmech.2012.12.024.

[115] D. Giacomini, R. Musumeci, P. Galletti, G. Martelli, L. Assennato, G. Sacchetti, A. Guerrini, E. Calaresu, M. Martinelli, C.E.A. Cocuzza, 4-Alkyliden-azetidinones modified with plant derived polyphenols: antibacterial and antioxidant properties, Eur. J. Med. Chem. 140 (2017) 604-614, https://doi.org 10.1016/j.ejmech.2017.09.048.

[116] F. Broccolo, G. Cainelli, G. Caltabiano, C.E.A. Cocuzza, C.G. Fortuna, P. Galletti, D. Giacomini, G. Musumarra, R. Musumeci, A. Quintavalla, Design, synthesis, and biological evaluation of 4-alkyliden-beta lactams: new products with promising antibiotic activity against resistant bacteria, J. Med. Chem. 49 (2006) 2804-2811, https://doi.org/10.1021/jm0580510.

[117] D. Giacomini, P. Torricelli, G.A. Gentilomi, E. Boanini, M. Gazzano, F. Bonvicini, E. Benetti, R. Soldati, G. Martelli, K. Rubini, A. Bigi, Monocyclic $\beta$ lactams loaded on hydroxyapatite: new biomaterials with enhanced antibacterial activity against resistant strains, Sci. Rep. 7 (2017) 2712, https:// doi.org/10.1038/s41598-017-02943-2.

[118] P.M. Orhan, B. Tekiner, S. Suzen, Recent studies of antioxidant quinoline derivatives, Mini Rev. Med. Chem. 13 (2013) 365-372, https://doi.org/ $10.2174 / 138955713804999793$.

[119] K.-H. Lam, R. Gambari, K.K.-H. Lee, Y.-X. Chen, S.H.-L. Kok, R.S.-M. Wong, et al., Preparation of 8-hydroxyquinoline derivatives as potential antibiotics against Staphylococcus aureus, Bioorg. Med. Chem. Lett 24 (2014) 367-370, https://doi.org/10.1016/j.bmcl.2013.10.072.

[120] B. Insuasty, D. Becerra, J. Quiroga, R. Abonia, M. Nogueras, J. Cobo, Microwave-assisted synthesis of pyrimido[4,5-b][1,6]naphthyridin-4(3H)-ones with potential antitumor activity, Eur. J. Med. Chem. 60 (2013) 1-9, https:// doi.org/10.1016/j.ejmech.2012.11.037.

[121] C.M. Melendez Gómez, V.V. Kouznetsov, M.A. Sortino, S.L. Álvarez S.A. Zacchino, In vitro antifungal activity of polyfunctionalized 2-(hetero) arylquinolines prepared through imino Diels-Alder reactions, Bioorg. Med. Chem. 16 (2008) 7908-7920, https://doi.org/10.1016/j.bmc.2008.07.079.

[122] Y. Xia, Z.Y. Yang, P. Xia, K.B. Bastow, Y. Tachibana, S.C. Kuo, E. Hamel, T. Hackl, K.H. Lee, Antitumor agents. synthesis and biological evaluation of 6,7,2, 3' 4' substituted-1,2,3,4-tetrahydro-2-phenyl-4-quinolones as a new class of antimitotic antitumor agents, J. Med. Chem. 41 (1998) 1155-1162, https:// doi.org/10.1021/jm9707479.

[123] S.J. Song, S.J. Cho, D.K. Park, T.W. Kwon, S.A. Jenekhe, Microwave enhanced solvent-free synthesis of a library of quinoline derivatives, Tetrahedron Lett. 44 (2003) 255-257, https://doi.org/10.1016/S0040-4039(02)02499-1.

[124] H.R.P. Naik, H.S.B. Naik, T.R.R. Naik, H.R. Naika, K. Gouthamchandra, R. Mahmood, B.M. Ahamed, Synthesis of novel benzo[h]quinolines: wound healing, antibacterial, DNA binding and in vitro antioxidant activity, Eur. J. Med. Chem. 44 (2009) 981-989, https://doi.org/10.1016 j.ejmech.2008.07.006.

[125] M. Iwaoka, S. Tomoda, A model study on the effect of an amino group on the antioxidant activity of Glutathione Peroxidase, J. Am. Chem. Soc. 116 (1994) 2557-2561, https://doi.org/10.1021/ja00085a040.

[126] M.D. Engelmann, E.R. Hutchenson, I.F. Cheng, Stability of ferric complexes with 3-hydroxyflavone (flavonol), 5,7-dihydroxyflavone (chrysin), and 3',4'dihydroxyflavone, J. Agric. Food Chem. 53 (2005) 2953-2960, https:// doi.org/10.1021/jf048298q.

[127] N. Kahriman, B. Yaylı, A. Aktas, Z. İskefiyeli, F.S. Beris, N. Yaylı, Synthesis, antibacterial and antioxidant activities of new 1-alkyl-4-(1-alkyl-4-oxo-1,4dihydroquinolin-2-yl)pyridinium bromides, Eur. J. Med. Chem. 69 (2013) 348-355, https://doi.org/10.1016/j.ejmech.2013.08.050.

[128] N. Kahriman, N.Y. Iskender, M. Yücel, N. Yayli, E. Demir, Z. Demirbağ, Microwave-assisted synthesis of 1,3'-diaza-flavanone/flavone and their alkyl derivatives with antimicrobial activity, J. Heterocycl. Chem. 49 (2012) 71-79, https://doi.org/10.1002/jhet.800.

129] S.K. Sahu, B.K. Dubey, A.C. Tripathi, M. Koshy, S.K. Saraf, Piperidin-4-one: the potential pharmacophore, Mini Rev. Med. Chem. 13 (2013) 565-583, https:/ doi.org/10.2174/1389557511313040009.

[130] S. Rollas, S.G. Kucukguzel, Biological activities of hydrazone derivatives, Molecules 17 (2007) 1910-1939, https://doi.org/10.3390/12081910.

[131] S.T. Harini, H.V. Kumar, J. Rangaswamy, N. Naik, Synthesis, antioxidant and antimicrobial activity of novel vanillin derived piperidin-4-one oxime esters preponderant role of the phenyl ester substituents on the piperidin-4-one oxime core, Bioorg. Med. Chem. Lett 22 (2012) 7588-7592, https://doi.org/ 10.1016/j.bmcl.2012.10.019.

[132] P. Paulrasu, A. Duraikannu, M. Palrasu, A. Shanmugasundaram, M. Kuppusamye, B. Thirunavukkarasu, Synthesis of 4-methyl-N'-(3-alkyl2r,6cdiarylpiperidin-4-ylidene)-1,2,3-thiadiazole-5-carbohydrazides with antioxidant, antitumor and antimicrobial activities, Org. Biomol. Chem. 12 (2014) 5911-5921, https://doi.org/10.1039/c4ob00739e.

[133] R. Narang, S. Narasimhan, A. Sharma, A review on biological activities and chemical synthesis of hydrazide derivatives, Curr. Med. Chem. 19 (2012) 569-612, https://doi.org/10.2174/092986712798918789.

[134] C. Sankar, K. Pandiarajan, Synthesis and anti-tubercular and antimicrobial activities of some 2r,4c-diaryl-3-azabicyclo[3.3.1]nonan-9-one $\mathrm{N}$-isonicotinoylhydrazone derivatives, Eur. J. Med. Chem. 45 (2010) 5480-5485, https://doi.org/10.1016/j.ejmech.2010.08.024.

[135] N. Karali, A. Gürsoy, F. Kandemirli, N. Shvets, F.B. Kaynak, S. Özbey, V.O. Kovalishyn, A. Dimoglo, Synthesis and structure-antituberculosis activity relationship of $1 \mathrm{H}$-indole-2, 3-dione derivatives, Bioorg. Med. Chem. 
15 (2007) 5888-5904, https://doi.org/10.1016/j.bmc.2007.05.063.

[136] T.M. de Aquino, A.P. Liesen, R.E. da Silva, V.T Lima, C.S. Carvalho, A.R. de Faria, J.M. de Araújo, J.G. de Lima, A.J. Alves, E.J. de Melo, A.J. Góes, Synthesis, anti-Toxoplasma gondii and antimicrobial activities of benzaldehyde 4phenyl-3-thiosemicarbazones and 2-[(phenylmethylene)hydrazono]-4-oxo3-phenyl-5-thiazolidineacetic acids, Bioorg. Med. Chem. 16 (2008) 446-456, https://doi.org/10.1016/j.bmc.2007.09.025.

[137] F. Vandresen, H. Falzirolli, S.A. Almeida Batista, A.P. da Silva-Giardini, D.N. de Oliveira, R.R. Catharino, A.L. Ruiz, J.E. de Carvalho, M.A. Foglio, C.C. da Silva, Novel $R-(+)$-limonene-based thiosemicarbazones and their antitumor activity against human tumor cell lines, Eur. J. Med. Chem. 79 (2014) 110-116 https://doi.org/10.1016/j.ejmech.2014.03.086.

[138] A. Cukurovali, I. Yilmaz, S. Gur, C. Kazaz, Synthesis, antibacterial and antifungal activity of some new thiazolylhydrazone derivatives containing 3substituted cyclobutane ring, Eur. J. Med. Chem. 41 (2006) 201-207, https://doi.org/10.1016/j.ejmech.2005.01.013.

[139] D.T. Nguyen, T.H. Le, T.T.T. Bui, Antioxidant activities of thiosemicarbazones from substituted benzaldehydes and $\mathrm{N}$-(tetra-O-acetyl-b-d-glucopyranosyl) thiosemicarbazide, Eur. J. Med. Chem. 60 (2013) 199-207, https://doi.org 10.1016/j.ejmech.2012.10.004.

[140] T. Bal-Demirci, M. Sahin, E. Kondakçı, M. Özyürek, B. Ülküseven, R. Apak, Synthesis and antioxidant activities of transition metal complexes based 3hydroxysalicylaldehyde-S-methylthiosemicarbazone, Spectrochim. Acta Part A Mol. Biomol. Spec. 138 (2015) 866-872, https://doi.org/10.1016 j.saa.2014.10.088.

[141] S. Ghosh, A.K. Misra, G. Bhatia, M.M. Khan, A.K. Khanna, Syntheses and evaluation of glucosyl aryl thiosemicarbazide and glucosyl thiosemicarbazone derivatives as antioxidant and anti-dyslipidemic, Bioorg Med. Chem. Lett 19 (2009) 386-389, https://doi.org/10.1016/ j.bmcl.2008.11.070.

[142] S.A. Pandeya, S. Smitha, M. Jyoti, S.K. Sridhar, Biological activities of isatin and its derivatives, Acta Pharm. 55 (2005) 27-46.

[143] P. Pakravan, S. Kashanian, M.M. Khodaei, F.J. Harding, Biochemical and pharmacological characterization of isatin and its derivatives: from structure to activity, Pharmacol. Rep. 65 (2013) 313-335.

[144] D.J. Bauer, P.W. Sadler, The structure-activity relationships of the antiviral chemotherapeutic activity of isatin b-thiosemicarbazone, Brit. Pharm. Chemother. 15 (1960) 101-110, https://doi.org/10.1111/j.14765381.1960.tb01216.x.

[145] N.D. Thanh, N.T.K. Giang, T.H. Quyen, D.T. Huong, V.N. Toan, Synthesis and evaluation of in vivo antioxidant, in vitro antibacterial, MRSA and antifungal activity of novel substituted isatin N-(2,3,4,6-tetra-O-acetyl- $\beta$-D-glucopyranosyl)thiosemicarbazones, Eur. J. Med. Chem. 123 (2016) 532-543, https:/ doi.org/10.1016/j.ejmech.2016.07.074.

[146] F. Lopez-Munoz, R. Ucha-Udabe, C. Alamo, The history of barbiturates a century after their clinical introduction, Neuropsychiatric Dis. Treat. 1 (2005) 329-343.

[147] J. Wang, M.W. Radomski, C. Medina, J.F. Gilmer, MMP inhibition by barbiturate homodimers, Bioorg. Med. Chem. Lett 23 (2013) 444-447, https:// doi.org/10.1016/j.bmcl.2012.11.063.

[148] K.M. Khan, M. Khan, A. Karim, M. Taha, N. Ambreen, A. Gojayev, S. Perveen, M. Choudhary, I. Xanthine oxidase inhibition by 5-aryledene N,N'-dimethylbarbituric acid derivatives, J. Chem. Soc. Pakistan 35 (2013) 495-498.

[149] R.M. Shaker, E.A. Ishak, Barbituric acid utility in multi-component reactions, Z. Naturforsch. 66b (2011) 1189-1201.

[150] G.M. Ziarani, F. Aleali, N. Lashgari, Recent applications of barbituric acid in multicomponent reactions, RSC Adv. 6 (2016) 50895-50922, https://doi.org/ 10.1039/C6RA09874F.

[151] K.T. Mahmudov, M.N. Kopylovich, A.M. Maharramov, M.M. Kurbanova, A.V. Gurbanov, A.J.L. Pombeiro, Barbituric acids as a useful tool for the construction of coordination and supramolecular compounds, Coord. Chem. Rev. 265 (2014) 1-37, https://doi.org/10.1016/j.ccr.2014.01.002.

[152] N. Kobra, K. Zahra, Barbituric acids in organic transformations, an outlook to the reaction media, Mini-rev. Org. Chem. 14 (2017) 143-173, https:/ doi.org/10.2174/1570193X14666170206122416.

[153] J. Figueiredo, J.L. Serrano, E. Cavalheiro, L. Keurulainen, J. Yli-Kauhaluoma, V.M. Moreira, S. Ferreira, F.C. Domingues, S. Silvestre, P. Almeida, Trisubstituted barbiturates and thiobarbiturates: synthesis and biological evaluation as xanthine oxidase inhibitors, antioxidants, antibacterial and antiproliferative agents, Eur. J. Med. Chem. 143 (2018) 829-842, https:// doi.org/10.1016/j.ejmech.2017.11.070.

[154] E. Tacconelli, N. Magrini, Global Priority List of Antibiotic-resistant Bacteria to Guide Research, Discovery, and Development of New Antibiotics, From World Health Organization website, 2017. http://www.who.int/entity/ medicines/publications/WHO-PPL-Short_Summary_25Feb-ET_NM_WHO. pdf?ua $=1$.

[155] F.V. Nussbaum, Stephacidin B-A new stage of complexity within prenylated indole alkaloids from fungi, Angew. Chem. Int. Ed. 42 (2003) 3068-3071 https://doi.org/10.1002/anie.200301646.

[156] J. Yu, T. Wang, X. Liu, J. Deschamps, J.F. Anderson, X. Liao, J.M. Cook, General approach for the synthesis of sarpagine indole alkaloids. enantiospecific total synthesis of $(+)$-vellosimine, $(+)$-normacusine $\mathrm{b},(-)$-alkaloid $\mathrm{q}_{3},(-)$-panarine, (+)- $N_{\mathrm{a}}$-methylvellosimine, and (+)- $N_{\mathrm{a}}$-methyl-16-epipericyclivine, J. Org. Chem. 68 (2003) 7565-7581, https://doi.org/10.1021/jo030006h.

[157] B. Ortner, R. Waibel, P. Gmeinwe, Indoloparacyclophanes: synthesis and dopamine receptor binding of a novel arylbioisostere, Angew. Chem. Int. Ed. 40 (2001) 1283-1285, https://doi.org/10.1002/1521-3773(20010401)40: 7<1283::AID-ANIE1283>3.0.CO;2-\#.

[158] E. Von Angerer, J. Strohmeier, 2-Phenylindoles, Effect of N-benzylation on estrogen receptor affinity, estrogenic properties, and mammary tumor inhibiting activity, J. Med. Chem. 30 (1987) 131-136, https://doi.org/ 10.1021/jm00384a022.

[159] E.J. Glamkowski, J.M. Fortunato, T.C. Spaulding, J.C. Wilker, D.B. Ellis, 3-(1Indolinyl)benzylamines: a new class of analgesic agents, J. Med. Chem. 28 (1985) 66-73, https://doi.org/10.1021/jm00379a014.

[160] P.C. Unangst, M.E. Carethers, K. Webster, G.M. Janik, L.J. Robichaud, Acidic furo[3,2-b]indoles. A new series of potent antiallergy agents, J. Med. Chem. 27 (1984) 1629-1633, https://doi.org/10.1021/jm00378a017.

[161] H. Sano, T. Noguchi, A. Miyajima, Y. Hashimoto, H. Miyachi, Anti-angiogenic activity of basic-type, selective cyclooxygenase (COX)-1 inhibitors, Bioorg Med. Chem. Lett 16 (2006) 3068-3072, https://doi.org/10.1016/ j.bmcl.2006.02.021.

[162] H. Xu, W.Q. Liu, L.L. Fan, Y. Chen, L.M. Yang, L. Lv, Y.T. Zheng, Synthesis and HIV-1 integrase inhibition activity of some n-arylindoles, Chem. Pharm. Bull. 56 (2008) 720-722, https://doi.org/10.1248/cpb.56.720.

[163] P. Rajakumar, N. Venkatesan, G. Mohanraj, Synthesis, antibacterial and antioxidant properties of novel ethylenoindolophanes - a new class of cyclophanes, RSC Adv. 4 (2014) 21190-21194, https://doi.org/10.1039/ c4ra00303a.

[164] K. Sharma, E.R. Baral, M.S. Akhtar, Y.R. Lee, S.H. Kim, Y.-J. Wee, 3Naphthylindoles as new promising candidate antioxidant, antibacterial, and antibiofilm agents, Res. Chem. Intermed. 43 (2017) 2387-2399, https:// doi.org/10.1007/s11164-016-2768-4.

[165] N.G. Aher, V.S. Pore, N.N. Mishra, A. Kumar, P.K. Shukla, A. Sharma, M.K. Bhat, Synthesis and antifungal activity of 1,2,3-triazole containing fluconazole analogues, Bioorg. Med. Chem. Lett 19 (2009) 759-763, https://doi.org/ 10.1016/j.bmcl.2008.12.026.

[166] G.L. Teja, D.V. Sowmya, A. Padmaja, V.K. Prasad, V. Padmavathi, Synthesis and antimicrobial activity of pyrazolyl triazoles, Med. Chem. 7 (2017) 361-367, https://doi.org/10.4172/2161-0444.1000481.

[167] MJ. Giffin, H. Heaslet, A. Brik, Y.C. Lin, G. Cauvi, C.H. Wong, D.E. McRee J.H. Elder, C.D. Stout, B.E. Torbett, A copper(I)-catalyzed 1,2,3-triazole azide-alkyne click compound is a potent inhibitor of a multidrug-resistant hiv-1 protease variant, J. Med. Chem. 51 (2008) 6263-6270, https:// doi.org/10.1021/jm800149m.

[168] S.R. Patpi, Pulipati, P. Yogeeswari, D. Sriram, N. Jain, B. Sridhar, R. Murthy, T.A. Devi, S.V. Kalivendi, S. Kantevari, Design, synthesis, and structure-activity correlations of novel dibenzo[b,d]furan, dibenzo[b,d] thiophene, and n-methylcarbazole clubbed 1,2,3-triazoles as potent inhibitors of mycobacterium tuberculosis, J. Med. Chem. 55 (2012) 3911-3922, https://doi.org/10.1021/jm300125e.

[169] R. Santosh, M.K. Selvam, S.U. Kanekar, G.K. Nagaraja, Synthesis, characterization, antibacterial and antioxidant studies of some heterocyclic compounds from triazole-linked chalcone derivatives, Chemistry 3 (2018) 6338-6343, https://doi.org/10.1002/slct.201800905.

[170] B. Srinivas, P.V. Kumar, P.N. Reddy, S. Venu, P. Shyam, G.L.D. Krupadanam, Design, synthesis, antioxidant and antibacterial activities of novel 2-((1benzyl-1h-1,2,3-triazol-4-yl)methyl)-5-(2hchromen-3-yl)-2h-tetrazoles,

Russ. J. Bioorg. Chem. 44 (2018) 244-251, https://doi.org/10.1134/ S1068162018020097.

[171] M.M. Khafagy, A.H.F.A. El-Wahas, F.A. Eid, A.M. El-Agrody, Synthesis of halogen derivatives of benzo[h]chromene and benzo[a]anthracene with promising antimicrobial activities, Farmaco 57 (2002) 715-722, https:// doi.org/10.1016/S0014-827X(02)01263-6.

[172] D.O. Moon, Y.H. Choi, N.D. Kim, Y.M. Park, G.Y. Kim, Anti-inflammatory effects of $\beta$-lapachone in lipopolysaccharide-stimulated BV2 microglia, Int. Immunopharm. 7 (2007) 506-514, https://doi.org/10.1016/ j.intimp.2006.12.006.

[173] D.R. Anderson, S. Hegde, E. Reinhard, L Gomez, W.F. Vernier, L. Lee, S. Liu, A. Sambanda, P.A. Sinder, L. Masih, Antimalarial activity of phenazines from lapachol, $\beta$-lapachone and its derivatives against Plasmodium falciparum in vitro and Plasmodium berghei in vivo, Bioorg. Med. Chem. Lett 15 (2005) 1587-1590, https://doi.org/10.1016/j.bmcl.2003.12.069.

[174] M. Ough, A. Lewis, E.A. Bey, J. Gao, J.M. Ritchie, W. Bornmann, D.A. Boothman, L.W. Oberley, J.J. Cullen, Efficacy of $\beta$-lapachone in pancreatic cancer treatment: exploiting the novel, therapeutic target NQ01, Canc. Biol. Ther. 4 (2005) 95-102, https://doi.org/10.4161/cbt.4.1.1382.

[175] R. Domalaon, T. Idowu, G.G. Zhanel, F. Schweizer, Antibiotic hybrids: the next generation of agents and adjuvants against gram-negative pathogens? Clin Microbiol. Rev. 31 (2018) e00077-17, https://doi: 10.1128/CMR.00077-17. 